\title{
Desordem e regresso: a "nova" reforma do ensino médio e a deficiência cívica sem o saber pensar o espaço e sem o saber nele agir
}

\author{
Disorder and regression: the "new" reform of high school and the civic \\ disability without knowing how to think the space and how to act on it
}

\author{
José Erimar dos Santos'
}

\begin{abstract}
RESUMO
O artigo apresenta um panorama geral acerca da "Nova" Reforma do Ensino Médio, abordando os aspectos estruturantes que qualificam tal mudança e que se refletem nas bases econômico pedagógicas, didático-pedagógicas, psicopedagógicas e pedagógico-administrativas influenciadoras, estruturadoras e dinamizadoras do sistema educacional brasileiro, no atual período geográfico - o período técnico-científico-informacional. O objetivo foi investigar a natureza dessa reforma, refletindo sobre suas principais características, o lugar da Geografia e as ideias pedagógicas que a constituem, através de investigação bibliográfica e documental envolvendo como base teórica contribuições de Milton Santos, Yves Lacoste e do educador Dermeval Saviani, dentre outros. Dentre os resultados, procura despertar para uma visão radical, crítica e contextualizante acerca das mudanças educacionais em voga com essa reforma, que, revestida de terminologias inovadoras (Base Nacional Comum Curricular, Itinerários Formativos...), percebidas nos documentos oficiais e discursos ideológicos, na realidade são antigas pretensões marcadas por descentramento e desconstrução de ideias pedagógicas anteriores, decorrentes das atuais mudanças no mundo do trabalho, ameaçando o futuro da disciplina e ciência Geografia e, portanto a cidadania.
\end{abstract}

Palavras-chave: Ensino de Geografia; Novo Ensino Médio; Neoprodutivismo

\section{ABSTRACT}

This article presents an overview about the "New" Reform of High School, approaching the structuring aspects that qualify such changes and reflect on the economic-pedagogic, didactic-pedagogic, psychopedagogic and pedagogic-administrative bases that influence, structure and stimulate the Brazilian educational system in the current geographic period - the technic-scientific-informational period. The objective was to investigate the nature of this reform, reflecting on its main characteristics, the place of Geography and the pedagogical ideas that constitute it, through bibliographical and documentary research involving has as theoretical base contributions from Milton Santos, Yves Lacoste and the teacher Dermeval Saviani, among others. As a result, it was verified the necessity of awakening to a radical, critical and contextualizing view concerning to the educational changes in vogue with that reform. Besides, the official documents and ideological discourses of that reform was coated with innovative terminologies (National Curricular Common Base, Formative Itinerary), but, in fact, they are old pretensions marked by decentralization and deconstruction of previous pedagogical ideas, coming 
from the current changes in the work market, threatening the future of geography as a science and a subject and, therefore, the citizenship.

Keywords: Geography Teaching; New High School; Neoprodutivism

\section{INTRODUÇÃO}

O logo e slogan do Governo Temer usa o lema positivista: "ordem e progresso" presente na bandeira do Brasil. Neste ensaio tomamos essas expressões em seu sentido antinômico: desordem e regresso, por entendermos que o pacote das "reformas" em curso realizadas por esse governo, dentre elas a do Ensino Médio, desordena e regride a Educação nacional, deformando a formação social dos jovens e contribuindo para formação de uma sociedade de deficientes cívicos, dada a desvalorização da construção da cidadania mediante a supressão de disciplinas no novo arranjo curricular da Educação Básica, a exemplo da Geografia.

O estudo é resultado das sistematizações de reflexões desenvolvidas no âmbito do Grupo de Estudos e Pesquisas Observatório das Desigualdades Socioespaciais, Dinâmicas Territoriais e Usos do Território no Semiárido Brasileiro. Caracteriza-se pela pesquisa bibliográfica em que investiga-se a natureza da "Nova" Reforma do Ensino Médio, refletindo-se sobre suas principais características, o lugar da Geografia frente essa reforma e as bases econômicopedagógicas, didático-pedagógicas, psicopedagógicas e pedagógicoadministrativas enquanto feições das ideias pedagógicas que estruturam esse intento do Ministério da Educação, das quais a Pedagogia das competências e a Pedagogia da exclusão includente constituem o eixo organizacional curricular e pedagógico dessa reforma, fazendo o ensino e a escola serem apropriados cada vez mais pelos processos produtivos, em que a natureza pedagógica assumida pela normativa e política educacional como um todo é protagonista de uma formação limitada.

Fundamentamo-nos, sobremaneira, em Milton Santos (1998a, 1998b, 2008a, 2008b, 2009), David Harvey (2008, 2014), Dermeval Saviani (2013) e Marise 
Ramos (2006), no sentido de buscarmos refletir as questões educacionais vinculadas às questões socioespaciais, como são de natureza constitutivas. Ao consideramos o espaço geográfico como um conjunto indissociável, contraditório, desigual e combinado de sistemas de objetos e sistemas de ações, implica o tê-lo como fato, fator e instância social (SANTOS, 2009, 2008b). O Espaço como fato significa que ele é um atributo material da superfície terrestre, sendo passível de ser medido, localizado, pois é uma realidade objetiva. Como fator ele é influenciador de todos os processos sociais, ora funcionando como estimulador, ora como inibidor desses processos. Por fim, como uma instância social, o espaço geográfico é indispensável às explicações da vida e dinâmica sociais. Sendo marcado por processos dos quais destacamos a mudança do modelo fordista de produção capitalista para o modelo de acumulação flexível (HARVEY, 2014), o arranjo organizacional da dispersão geográfica dos sistemas de objetos e dos sistemas de ações conformadores dessa racionalidade do capital não deixa de lado as dinâmicas normativas do sistema educacional. Por essa razão, nos apoiamos em Ramos (2006) e Saviani (2013). A primeira, problematizando a noção de competência como eixo central das dinâmicas e reformas educacionais, no Brasil, nos últimos anos, possibilita-nos ancorar a natureza da atual reforma do Ensino Médio à uma lógica mais completa da qual ela faz parte. O segundo, Saviani (2013), tomando o lapso temporal (1991-2001) nos faz compreender as ideias pedagógicas produtivistas presentes na educação nacional, das quais essa Reforma no Ensino Médio não deixa de ser uma continuidade.

A tese que aqui defendemos é a de que as dinâmicas verificadas no âmbito da Educação nacional, tomando a situação da Reforma no Ensino Médio é uma dinâmica vinculada à maneira como o Estado toma para si suas relações com o tempo e com o espaço, pois são recorrentes afirmações simultâneas relativas às dimensões tempo e espaço no sentido de mutações, mudanças, transformações, adequações, nesse processo de reforma... Por fazer parte de um sistema de 
ações de natureza dialética, a Lei $N^{\circ}$. 13.415, de 16 de fevereiro de 2017, não considera o Ensino Médio em seu quadro geral no território nacional e nem tampouco o contexto em que se encontra a escola pública no país, marcada por um déficit estrutural de recursos humanos e infraestruturais. Sua elaboração e promulgação partem de uma ânsia travestida de um desejo e discurso eficaz, porém errônea, do Governo Temer, de buscar resolver problemas de qualidade ligados a esta etapa da educação. A partir do discurso da flexibilidade, autonomia dada aos jovens de poder fazer escolhas, a referida reforma constitui-se em redução da Educação Básica à preparação para o mercado de trabalho, com isso, reforçando a dualidade da educação nacional (educação para a elite e educação para os filhos da classe trabalhadora) ampliando, pois, as desigualdades educacionais com a restrição e abreviação da oferta dessa etapa educacional, já que dá base legal para privatização do ensino público gerando, com isso, o aprofundamento das desigualdades escolares e regionais existentes em nossa formação socioespacial. Dessa forma, essa reforma reforça a institucionalização de dois percursos formativos: 1) um direcionado aos estudantes de escolas públicas que se voltará para a formação técnica e profissional de mão de obra para o mercado de trabalho e, 2) um outro destinado e/ou a ser realizado pelas instituições escolares privadas, em que terá como foco formar para o ensino superior. Isso é preocupante, porque, de um lado, se constituirá com mais evidência um grupo de jovens específicos que terá acesso às profissões mais prestigiadas e mais bem remuneradas, que são aqueles jovens de proveniência de classes sociais mais privilegiadas economicamente e, por outro lado uma massa que comporá o mercado de trabalho de empregáveis, pois o acesso aos cursos técnicos não são sinônimo de emprego após o seu término, sobretudo nesse período técnico-científico-informacional.

Procuramos comprovar isso a partir da reflexão organizada em três partes: 1) exposição das principais características da reforma do "Novo" Ensino Médio presentes na Lei $N^{\circ}$. 13.415, de 16 de fevereiro de 2017. 2) problematização 
acerca da ausência de se saber pensar o espaço geográfico que implica no não saber nele agir, já que a ciência geográfica e o Ensino de Geografia dado através da Disciplina Geografia, na escola, passa a ser um conhecimento ausente nessa reforma. Em outras palavras, problematizamos o lugar da Geografia no contexto dessa reforma e o impacto negativo que sua ausência gerará à sociedade nacional. 3) reflexão sobre as velhas ideias pedagógicas travestidas e ressignificadas de novas terminologias, onde discutiremos as bases econômicopedagógicas, didático-pedagógicas, psicopedagógicas e pedagógicoadministrativas que fundamentam essa reforma do Ensino Médio.

Para tanto, antes de adentramos nessas discussões discutiremos, inicialmente, alguns conceitos e categorias de análise importantes aos quais se liga o tema aqui em discussão. Como premissa, partimos do que atesta o geógrafo Milton Santos (2008a, p. 115-116), para quem: “Para ter eficácia, o processo de aprendizagem deve, em primeiro lugar, partir da consciência da época em que vivemos. Isso significa saber o que o mundo é e como ele se define e funciona, de modo a reconhecer o lugar de cada país no conjunto do planeta e o de cada pessoa no conjunto da sociedade humana".

A época em que vivemos é caracterizada pelo avanço da técnica, da ciência e da informação, que configurando os processos produtivos e de dinâmicas do capitalismo contemporâneo, reconfigura os processos, as formas, as funções e a estrutura socioespacial. A esse período, Santos (2008a, 2009) denominou de Período Técnico-científico-informacional. Trata-se de perceber que, a época em que vivemos, é uma combinação específica de técnicas dinamizada pela racionalidade política e econômica. É um período em totalização, propulsor de um meio geográfico de mesmo nome em que a presença da técnica, da ciência e da informação, a serviço da financeirização mundial e do território (CHESNAIS, 1998, 2005; SANTOS, SILVEIRA, 2002), é uma constante em todas as instâncias socioespaciais. Iniciou-se, esse momento, com o fim da Segunda Guerra Mundial 
(SANTOS, 1994; 2008a; 2009; SANTOS, SILVEIRA, 2002) e estendendo-se, no caso brasileiro, a partir da década de 1970. Portanto, a época em que vivemos é caracterizada por uma situação em que "[...] a ciência e a tecnologia, junto com a informação, estão na própria base da produção, da utilização e do funcionamento do espaço e tendem a constituir o seu substrato" (SANTOS, 2009, p. 238), criando novos processos, novas funções, novas formas e reconfiguração da estrutura socioespacial, através da reestruturação produtiva (HARVEY, 2014).

Forma, função, estrutura e processo, “[...] representam o verdadeiro movimento da totalidade, o que permitirá fragmentá-la para em seguida reconstruí-la" (SANTOS, 2008c, p. 77). "Forma é o aspecto visível de uma coisa. Refere-se, ademais, ao arranjo ordenado de objetos, a um padrão. Tomada isoladamente, temos uma mera descrição de fenômenos ou de um de seus aspectos num instante do tempo". A Função é "[...] uma tarefa ou atividade esperada de uma forma, pessoa, instituição ou coisa". Já "Estrutura implica a inter-relação de todas as partes de um todo; o modo de organização ou construção", ou seja, diz respeito à natureza econômica, política e social de uma nacionalidade. E, por fim, o Processo é a “[...] uma ação contínua, desenvolvendose em direção a um resultado qualquer, implicando conceito de tempo (continuidade) e mudança" (SANTOS, 2008c, p. 69). Isso é extremamente importante, no sentido de que, enquanto Ser, que “[...] é a sociedade total; o tempo são os processos, e as funções, assim como as formas são a existência" (SANTOS, 2008b, p. 218) dos lugares expressa em suas formas-conteúdo e nos usos.

A normatização enquanto parte do sistema de ações do Estado em nome do Mercado, se faz com o uso das normas. Enquanto leis e/ou regras criadas pelo Estado e suas instituições regulam e/ou desregulam as ações dos elementos do espaço, facultando ou não a geografização dos eventos no território. A norma é uma categoria fundamental no conhecimento e compreensão do espaço 
geográfico, já que ajuda no desvelamento dos processos, pois através dela entendemos como as materialidades se desdobram em ações e as ações em materialidades e sabemos quem usa e quem regula o território. Nesse sentido, norma é aqui entendida como as ações políticas e/ou institucionais, criadas e implementadas para regular as ações e os eventos territoriais. Em outras palavras, "[...] a norma é geneticamente uma ação e morfologicamente uma densidade, uma forma" (SILVEIRA, 1999, p. 257).

Por fim, uma categoria de análise à qual a desordem e o regresso decorrentes da "Nova" Reforma do Ensino Médio está relacionada, quando a perspectiva é uma abordagem geográfica, é a noção de território usado, uma ideia que Milton Santos propôs em 1994 no texto O Retorno do Território, em que afirma que "é o uso do território, e não o território em si mesmo, que faz dele objeto da análise social" (SANTOS, 1998a, p. 15). O uso do território pelo Estado é o cerne do processo pelo qual se liga o pacote de reformas do atual governo, o qual está a Reforma do Ensino Médio, pois implica no uso político do território, que envolve o funcionamento político (norma) de um momento que busca atender uma função no conjunto das relações e da conformação de uma sociedade destinada a um fim específico: cada vez mais a racionalidade do Mercado Econômico.

Feito isso, passemos à reflexão das principais características da Reforma do "Novo" Ensino Médio buscando, mediante essas referências categóricas, compreender a lógica do sistema de ações para à qual essa reforma foi pensada, de modo a reconhecer o lugar da Geografia nesse processo e de parte dos sujeitos sociais no conjunto das dinâmicas em curso no conjunto da sociedade humana capitalista contemporânea, em que a Educação é eixo central na dinamização de uma nova realidade em construção, marcada por usos e abusos por parte do Estado e dos seus sistemas de ações. 


\section{CARACTERÍSTICAS DA REFORMA DO “NOVO” ENSINO MÉDIO}

A “Nova” Reforma do Ensino Médio, implantada no dia 17 de fevereiro de 2017, através da publicação da Lei Nº 13.415, no Diário Oficial da União, faz um conjunto de alterações na Lei de Diretrizes e Bases da Educação Nacional (Lei Nº. 9.394/1996), impondo transformações no currículo, na organização do Ensino Médio e na profissão docente. Neste tópico, abordaremos algumas características dessa lei, que os reformuladores chamam de Novo Ensino Médio e, que, em linhas gerais, aprofunda desigualdades já existentes na formação educacional dos jovens brasileiros.

Tal reforma foi anunciada através de um ato normativo, a Medida Provisória No. 746, de 22 de setembro de 2016, como um ato típico do autoritarismo que caracteriza o atual governo brasileiro, já que implica em dinâmicas estruturais no Ensino Médio sem as devidas considerações. É um ato autoritário no sentido de que não levou em consideração as necessidades reais de mudanças que esse nível de ensino realmente precisa e que tão bem apontam vários pesquisadores brasileiros que há anos estudam este nível de ensino e que tão bem conhecem a classe trabalhadora a ele ligado. É autoritário porque não toma o Plano Nacional de Educação (PNE (2014/2024))i como norteador dos sistemas de ações voltadas às dinâmicas e mudanças na educação, mas é implantada em obediência aos ditames dos organismos internacionais financeiros e econômicos e em nome da classe econômica nacional, deixando de lado várias das metas estipuladas pelo PNE (2014/2024).

De acordo com o Ministério da Educação, o Plano Nacional de Educação (2014/2024) constitui-se de diretrizes, metas e estratégias essenciais para a política educacional do país em um certo intervalo de tempo. No plano em vigor, o primeiro grupo de metas consiste de metas estruturantes que visam garantir o acesso, a universalização do ensino obrigatório e a ampliação das oportunidades educacionais. Já no segundo grupo de metas, encontram-se aquelas relacionadas 
à redução das desigualdades e à valorização da diversidade, e é justamente este grupo que a atual Reforma do Ensino Médio não levou em consideração, pois são caminhos indispensáveis à equidade socioespacial. Somando-se ao terceiro grupo de metas que trata da valorização dos profissionais da educação e ao quarto que versa sobre o Ensino Superior, a Lei №. 13.415, de 16 de fevereiro de 2017 deixa clara a não consideração do PNE/2014-2024 em sua formulação e promulgação. Embora esteja como estratégia - estratégia 3.1 alguns elementosii que são relativos a essa reforma, a mesma foge na sua maior parte das diretrizes e das metas do PNE/2014-2024. Em suma, ao passo que, dentre outros elementos, o PNE/2014-2024 apregoa que todos os professores e professoras da Educação básica devam ter graduação na área de conhecimento em que atuam, a atual Reforma do Ensino Médio dar possibilidades para profissionais com "notório saber" dá aulas de conteúdos de áreas afins à sua formação. Dessa forma, essa lei se constitui com muitas interrogações sobre o futuro do Plano Nacional de Educação.

Constitui-se esta reforma ainda em mais um dos componentes conservadores do pacote de mudanças impostas pelo Governo Temer. Como enfatizamos anteriormente, através do seu slogan, esse governo busca recolocar o Brasil nos trilhos do neoliberalismo impondo um conjunto de reformas e, dentre essas reformas, a da Educação (do Ensino Médio).

Há de se ressaltar, entretanto que, é inegável e urgente reforma no Ensino Médio no Brasil, em função das desigualdades sociais, diversidade cultural do país e das condições de oferta educacional que o país tem e das condições estruturais da escola pública e da valorização dos profissionais da Educação. No entanto, como se notou com a medida provisória o autoritarismo desconsiderou tais nuances, pois após ser sancionada foi aprovada com muita rapidez, como, aliás, tem acontecido com o conjunto das demais reformas que o referido governo vem impondo no país. 
Essa proposta de reforma carrega uma filosofia pragmática, no sentido de reduzir o sentido da Educação apenas aos aspectos da utilidade econômica, limitando-se aos efeitos práticos, de valor utilitário do sistema capitalista. Não queremos negar, com isso, a relação que o sentido da Educação tem com a existência humana, e que a existência humana é separada do trabalho, pois

\begin{abstract}
Sabe-se que a educação é um fenômeno próprio dos seres humanos. Assim sendo, a compreensão da natureza da educação passa pela compreensão da natureza humana. Ora, o que diferencia os homens dos demais fenômenos, o que o diferencia dos demais seres vivos, o que o diferencia dos outros animais? [...] sabe-se que, diferentemente dos outros animais, que se adaptam à realidade natural tendo a sua existência garantida naturalmente, o homem necessita produzir continuamente sua própria existência. [...] em lugar de se adaptar à natureza, ele tem que adaptar a natureza a si, isto é, transformá-la. E isto é feito pelo trabalho. Portanto, o que diferencia o homem dos outros animais é o trabalho. E o trabalho instaura-se a partir do momento em que seu agente antecipa mentalmente a finalidade da ação. Conseqüentemente, o trabalho não é qualquer tipo de atividade, mas uma ação adequada a finalidades. É, pois, uma ação intencional. Para sobrevier, o homem necessita extrair da natureza, ativa e intencionalmente, os meios de sua subsistência. Ao fazer isso, ele inicia o processo de transformação da natureza, criando um mundo humano (o mundo da cultura) (SAVIANI, 2008, p. 11)iii.
\end{abstract}

Portanto, “[...] a compreensão da natureza da educação enquanto um trabalho não-material, cujo produto não se separa do ato de produção, permitenos situar a especificidade de educação como referida aos conhecimentos, ideias, conceitos, valores, atitudes, hábitos, símbolos sob o aspecto de elementos necessários à formação da humanidade em cada indivíduo singular, na forma de uma segunda natureza, que se produz, deliberadamente e intencionalmente, através de relações pedagógicas historicamente determinadas que se travam entre os homens" (SAVIANI, 2008, p. 22; grifos nossos).

Com essa reforma, constatamos que a especificidade da educação enquanto um processo de transmissão-assimilação de "conhecimentos, ideias, conceitos, valores, atitudes, hábitos, símbolos sob o aspecto de elementos necessários à formação da humanidade em cada indivíduo singular" (SAVIANI, 2008, p. 22) passa a ser comprometida, sobretudo quando constatamos ainda que "de agência destinada a atender o interesse da população pelo acesso ao 
saber sistematizado, a escola passa a ser uma agência a serviço de interesses corporativistas ou clientelistas" (SAVIANI, 2008, p. 17).

Sem o saber pensar o espaço geográfico e sem o saber nele agir, dada a diluição da disciplina de Geografia no novo arranjo curricular imposto por essa nova reforma, resta aos jovens tornarem-se cada vez mais incluídos-excluídos. Excluídos do mercado de trabalho e alienados aos processos, formas, funções e aspectos estruturais que norteiam a sociedade e o espaço nacionais, sobretudo os filhos da classe trabalhadora, uma vez que a estes as condições impostas para serem partícipes de uma sociedade e dos processos a ela inerentes na condição de exército de reserva se acentuam. Incluídos porque passam a somarem-se à uma massa de empregáveis existente, mantida e controlada pelo Estado e Mercado Econômico, por meio das falsas políticas de inclusão existentes do Estado Neoliberal brasileiro.

A volta do Ensino Técnico vem nessa direção. Esse ensino técnico não é pensado e planejado para os filhos da classe abastarda, mas sim para os filhos da classe trabalhadora, pois no rol dos desdobramentos existenciais da vida cotidiana desse mundo moderno que levam, é o que Ihes restará: fazer cursos técnicos e ficarem sem emprego, somando-se aos demais empregáveis existentes, já que a entrada para o Ensino Superior passa a ser cada vez mais difícil mediante a supressão das possibilidades do conhecimento sistematizado que Ihes são retirados e negados. Com essa reforma, a Educação ofertada à classe trabalhadora brasileira passa a ser cada vez mais expressão do desenvolvimento desigual e combinado (RUMMERT, ALGEBAILE, VENTURA, 2013). A Educação dual reforçada com esta reforma é mais uma das “[...] facetas da totalidade da qual faz parte o Brasil atual, ainda guardião de valores históricos da nossa forma particular de dominação burguesa e da mentalidade de longa duração herdada do período colonial e escravista, que, em simultâneo, busca firmar sua integração subalterna no atual cenário internacional" (RUMMERT, ALGEBAILE, VENTURA, 2013, p. 717). 
De acordo com Gramsci (1982, p. 118),

A tendência, hoje, é a de abolir qualquer tipo de escola 'desinteressada' (não imediatamente interessada) e 'formativa', ou conservar delas tão-somente um reduzido exemplar destinado a uma pequena elite de senhores e de mulheres que não devem pensar em se preparar para um futuro profissional, bem como a de difundir cada vez mais as escolas profissionais especializadas, nas quais o destino do aluno e sua futura atividade são predeterminados.

Não apenas na época em que Gramsci escreveu essas assertivas - primeira metade do século XX -, mas também no cenário atual do Brasil é perceptível essa realidade para uma organização da escola destinada “[...] às classes instrumentais, ao passo que a clássica destina[-se] às classes dominantes e aos intelectuais" (GRAMSCI, 1982, p. 118).

Os proponentes dessa reforma argumentam sustentando-se numa concepção de que o Ensino Médio no Brasil é o principal desafio da Educação nacional afirmando, os reformuladores, haver um quadro de estagnação quanto a esse nível de ensino. Baseando-se na pesquisa da Fundação Sistema Estadual de Análise de Dados (SEADE, 2013), com base nas informações da Pesquisa Nacional por Amostra por Domicílios (PNAD) do IBGE, que afirma que "Apenas metade dos jovens de 15 a 17 anos está cursando o ensino médio e mais do que dobrou a proporção dos que abandonaram a escola na última década" (SEADE, 2013, p. 4). Atesta ainda este estudo que

A proporção dos jovens de 15 a 17 anos cursando o ensino médio é inferior a 51\% (2011); entre 1999 e 2011, mais que dobrou a proporção dos que abandonaram a escola no ensino médio (de $7,4 \%$ para $16,2 \%$ ); a proporção dos que nem trabalham, nem estudam atinge $24 \%$ dos jovens com 18 anos de idade e $25 \%$ daqueles com 20 anos; $58,3 \%$ dos que não estudam e não trabalham estão entre as famílias com renda familiar inferior a dois salários mínimos; os indicadores de desempenho escolar praticamente não se alteraram na comparação entre 1999 e 2011, apesar dos esforços realizados pelo setor público nesse campo (SEADE, 2013, p. 5).

Tais dados constituem-se nos argumentos centrais da reforma, no sentido de que o equacionamento dessa problemática deve passar, segundo os reformuladores e este próprio estudo do Seade (2013, p. 4), “[...] pela revisão do 
currículo, pela integração com a educação profissional e por uma política de diversificação do ensino médio".

Um dos elementos constitutivos do discurso do Ministério da Educação (MEC) e do atual governo brasileiro é o de inculcar na mente dos jovens que o Estado está dando prioridade às necessidades individuais dos estudantes, como se percebe nas propagandas do MEC veiculadas na mídia, além de usarem o discurso comparando o Ensino Médio do Brasil aos dos países mais avançados do mundo.

Dadas essas considerações, passemos a uma análise mais detalhada da Lei No. 13.415, de 16 de fevereiro de 2017, a fim de comprovarmos algumas constatações mencionadas, fazendo considerações acerca desta normativa.

A norma mencionada é uma conversão da Medida Provisória Nº. 746, de 22 de setembro de 2016, e visa alterar as seguintes leis: a) Lei N. 9.394, de 20 de dezembro de 1996 (LDB/1996), que estabelece as diretrizes e bases da educação nacional e b) a Lei No. 11.494, de 20 de junho de 2017, que regulamenta o Fundo de Manutenção e Desenvolvimento da Educação Básica e de Valorização dos Profissionais da Educação (FUNDEB). Esta última é a maior fonte de financiamento da educação básica, que passa a financiar a oferta de serviços educacionais realizados por agentes não públicos, como é o caso da educação técnica e profissional, fato que abre cada vez mais brecha para a privatização da educação pública nacional. Além disso, impacta também a Consolidação das Leis do Trabalho (CLT), aprovada pelo Decreto-Lei $N^{\circ} .5 .452$, de $1^{\circ}$ de maio de 1943 e o Decreto-Lei No. 236, de 28 de fevereiro de 1967. Por fim, revoga a Lei No. 11.161, de 5 de agosto de 2005, que versava sobre o ensino de Língua Espanhola e, apregoa instituir a Política de Fomento à implementação de Escolas de Ensino Médio em Tempo Integral. Dessa forma, pelas alterações elencadas, percebemos a complexidade dos processos que visam certas funções mediante a estrutura econômica, social e cultural brasileira que essa reforma do Ensino Médio visa efetivar. 
Sobre alterações na LDB/1996, altera a carga horária do Ensino Fundamental e Médio, a partir da modificação do Art. 24 dessa lei, como se percebe no inciso I, onde estipula que a carga horária mínima será de oitocentas horas para o Ensino Fundamental e para o Ensino Médio. No parágrafo $1^{\circ}$, se lê que a carga horária mínima anual deverá ser ampliada de maneira progressiva, no Ensino Médio, para mil e quatrocentas horas, deixando os sistemas de ensino ofertar, dentro do prazo de cinco anos, pelo menos mil horas anuais de carga horária. Apregoa ainda, no parágrafo $2^{\circ}$ desse mesmo inciso a oferta de Educação de Jovens e Adultos e de caráter noturno regular. Disso, duas considerações podem ser feitas, sendo uma, uma interrogação, e a outra uma constatação, de fato: 1) como, já de início, aumentar a carga horária, fato que implica em gastos e quando a proposta do governo é cortes? Assim, a Lei No. 13.415, de 16 de fevereiro de 2017, isto é, a reforma do Ensino Médio, precisa ser analisada, necessariamente em conjunto com a reforma fiscal que estabelece o fim dos vínculos constitucionais para a área da educação e congela os recursos financeiros por vinte anos. Essa situação coloca em mais evidência a realidade da escola pública no Brasil, no sentido de que terão que improvisar mais para atender suas demandas e tornando mais presente as influências empresariais nas lógicas organizacionais da Educação através da parceria que deverá se estabelecer entre setor público e setor privado no tocante à operacionalidade da Educação Técnica e Profissional. Toda essa realidade implica, em cada vez mais, desresponsabilidade do Estado para com a Educação pública no país. 2) a oferta de Educação a jovens e adultos em regime noturno já evidencia o caráter dual de início pela qual essa reforma foi pensada: colocar de um lado os filhos da classe trabalhadora e, de outro, os filhos das classes mais abastardas.

Dessa forma, essa normativa reduz a carga horária de formação geral passando de 2.400 para 1.400 horas. Do ponto de vista operacional isso não se efetiva em redução no sentido de que a formação cultural e científica dos jovens estudantes se voltará para preparação de estudos complementares em uma das 
áreas de formação que supostamente a escola deverá ofertar, incluindo-se aí, sobretudo, formação para o mercado de trabalho.

O segundo artigo alterado é o Art. 26 da Lei Nº 9.394, de 20 de dezembro de 1996, instituindo o Ensino da Arte em suas expressões regionais como componente curricular obrigatório e o ensino de Língua Inglesa a partir do sexto ano do Ensino Fundamental. À esta lei ainda é acrescentado o Art. 35-A, que trata da definição dos direitos e objetivos da aprendizagem do Ensino Médio, dados a partir da Base Nacional Comum Curricular, em obediência às áreas de conhecimento. Dessa forma, "A Base Nacional Comum Curricular definirá direitos e objetivos de aprendizagem do ensino médio, conforme diretrizes do Conselho Nacional de Educação, nas seguintes áreas do conhecimento: I - linguagens e suas tecnologias; II - matemática e suas tecnologias; III - ciências da natureza e suas tecnologias; IV - ciências humanas e sociais aplicadas" (BRASIL, 2017).

Como percebemos as ciências humanas básicas, a exemplo da Geografia e da História, a partir deste inciso IV são decretadas mortas, inexistentes nessa "Nova" Reforma. Isso significa que, por meio da Base Nacional Comum Curricular, referente ao Ensino Médio, a Geografia não se faz presente no currículo, já que "A Base Nacional Comum Curricular referente ao ensino médio incluirá obrigatoriamente estudos de educação física, arte, sociologia e filosofia" (BRASIL, 2017) e o estudo de língua inglesa, ficando a União responsável pelo estabelecimento dos padrões de desempenho esperados para o Ensino Médio, como já é feito como o Exame Nacional do Ensino Médio (ENEM). Tais sistemas de ações compromete significativamente em termos negativos a formação dos jovens, apesar de frisar essa norma que tal reforma considera “[...] a formação integral do aluno, de maneira a adotar um trabalho voltado para a construção de seu projeto de vida" (BRASIL, 2017), no sentido de que resta apenas a acentuação da dualidade educacional. Além disso, responsabiliza o aluno pelo seu sucesso ou fracasso e exime o Estado de suas funções constitucionais para com a Educação dos jovens do Ensino Médio. 
Por essas razões, o Art. 36 da LDB/1996 é alterado, passando a estabelecer a composição do currículo do Ensino Médio, onde disciplinas como a Geografia e a História nem sequer são mencionadas, já que aparecem novos arranjos curriculares, como a Base Nacional Comum Curricular e os itinerários formativos: “O currículo do ensino médio será composto pela Base Nacional Comum Curricular e por itinerários formativos, que deverão ser organizados por meio da oferta de diferentes arranjos curriculares, conforme a relevância para o contexto local e a possibilidade dos sistemas de ensino" (BRASIL, 2017). Tais arranjos são as áreas de linguagens e suas tecnologias; matemática e suas tecnologias; ciências da natureza e suas tecnologias; ciências humanas e sociais aplicadas e formação técnica e profissional.

Toda essa organização é preocupante, porque deverá ser realizada, do ponto de vista da operacionalidade, pelos sistemas de ensino, que como já sabemos, encontram-se cada vez mais defasados, dado o modo político como são organizados pelo Estado. A flexibilização curricular por meio de itinerários formativos diversos vis no sentido de uma pedagogia das competências, dada pelas escolas que ofertarão e definirão e não a partir dos interesses e aspirações das escolas e dos estudantes, como o governo quer fazer crer. É a realidade de descaso para com a Educação mais cruel que possa se mencionar. Isso representa um engodo com implicações sem proporções na vida de uma sociedade. Quem, de fato, escolhe e quem define os itinerários formativos são os sistemas de ensino, que por sua vez estão condicionados à certas condições econômicas, estruturais e logísticas às quais já conhecemos no cenário geográfico nacional: pouca disponibilidade de professores, péssimas condições estruturais etc., e, não os jovens que escolherão. Isso é absurdo. Desse modo, as premissas de que “[...] os jovens poderão escolher o currículo mais adaptado às suas necessidades e vocações", como percebemos nas propagandas do MEC, é uma falácia e um engodo, típico de um Estado que visa, com esses sistemas de ações, um projeto de desmonte do direito constitucional educacional. 
No tocante à oferta da formação técnica e profissional é outro fator também de responsabilidade dos sistemas de ensinos (escolas e secretarias municipais e estaduais de educação), já que as escolas deverão fazer parcerias com o setor produtivo ou com ambientes de simulação. Um fator preocupante refere-se à carência de docentes devidamente habilitados para o exercício profissional no tocante à atuação nos "itinerários formativos". Em decorrência disso, pelas características que já tem, o ensino público priorizará a “formação técnica e profissional", no sentido de que nessa área poderão atuar os "profissionais com notório saber" e, porque terá a maioria da massa jovem frequentando: os filhos da classe trabalhadora. Além disso, impõe às escolas organizarem também o Ensino Médio em módulos e adotar sistema de créditos com terminalidade específica para o cumprimento das exigências curriculares desse ensino. Por fim, as escolas também poderão firmar convênios com instituições de educação a distância com notório conhecimento visando o cumprimento das exigências curriculares.

Outro aspecto modificado diz respeito ao perfil profissional de pessoal a ensinar, uma vez que altera o Art. 61 da Lei n. 9.394, de 20 de dezembro de 1996, deixando evidente que profissionais com notório saber poderão ministrar conteúdos de áreas afins à sua formação ou experiência profissional. Além disso, aponta para mudanças nos currículos dos cursos de formação de docentes que terão que ter por referência a Base Nacional Comum Curricular. Tal concepção é uma visão liberal, antiga e tradicional, já combatida, inclusive por Comenius (2006) em sua Didática Magna, obra datada do século XVII, onde descreve métodos de trabalho que o professor deveria ter para ensinar. Não basta para um professor apenas saber seu conteúdo. Isso é fundamental, mas não basta, conforme também evidencia José Carlos Libâneo em sua Didática, ao falar das duas dimensões articuladas que constituem a formação do professor: 
docente vai especializar-se e a formação pedagógica, que envolve os conhecimentos da Filosofia, Sociologia, História da Educação e da própria Pedagogia que contribuem para o esclarecimento do fenômeno educativo no contexto histórico-social; a formação técnico-prática visando à preparação profissional específica para a docência, incluindo a Didática, as metodologias específicas das matérias, a Psicologia da Educação, a pesquisa educacional e outras (LIBÂNEO, 2011, p. 27; grifos do autor).

Nesta mesma obra, Libâneo afirma que, sendo intencional, a prática docente não basta apenas instruir e, que, para ensinar é preciso desenvolver ações, meios e condições para a realização da instrução, fato que parece não serem mais mecanismos significativos com a "Nova" Reforma do Ensino Médio.

Sobre alterações na Consolidação das Leis do Trabalho (CLT), a referida norma altera o Art. 318 da CLT, aprovada pelo Decreto-Lei $N^{\circ}$. 5.425, de $1^{\circ}$ de maio de 1943, facultando ao professor lecionar em um mesmo estabelecimento de ensino por mais de um turno, o que faz com que, com essa "nova" normativa, a educação passa a ser estruturada cada vez mais nos moldes empresariais.

Um futuro incerto quanto ao financiamento da Educação Média é deixado transparecer nessa normativa do "novo" Ensino Médio, por dois motivos: 1) a lei afirma que “[...] fica instituída, no âmbito do Ministério da Educação, a Política de Fomento à implantação de Escolas de Ensino Médio em Tempo Integral" (BRASIL, 2017). No entanto, deixa vago a questão da transferência desses recursos, no sentido de que “[...] a transferência de recursos será realizada anualmente, a partir de valor único por aluno, respeitada a disponibilidade orçamentária para atendimento, a ser definida por ato do Ministro de Estado da Educação" (BRASIL, 2017; grifos nossos). Esta última é a constatação mais evidente de que o Plano Nacional e Estaduais de Educação ficam realmente sem sentido, uma vez que o financiamento para a manutenção da Educação fica à mercê de orçamento disponível e da vontade deliberativa do Ministro da Educação, fato que não passa de autoritarismo e de um uso e abuso para com a Educação pública nacional. 
Já caminhando para o final da reflexão deste tópico há de afirmar que esse ato normativo revoga a Lei $n^{\circ}$. 11.161, de 5 de agosto de 2005, que dispunha sobre o ensino de Língua Espanhola, já que como se viu anteriormente, tornou o ensino dessa língua facultativo às escolas públicas, optando pelo ensino de Língua Inglesa, fato que nos faz inferir algumas notas: a) o ensino de Língua Espanhola nos aproxima dos povos da América do Sul; b) o ensino de Língua Inglesa nos formata mais significativamente aos desígnios e subordinação do Estado neoliberal e ao processo de globalização norte-americana, ou seja, à cultura unipolar capitalista que tem o inglês como idioma oficial e o dólar como moeda oficial. Essa premissa nos faz pensar na ordem geopolítica mundial em que insere cada vez mais o Brasil nos moldes relacionais de subordinação do capitalismo ditado pelas grandes potências, a exemplo da norte-americana, já que se cortam as relações com os países vizinhos e se caminha mais intensamente à subordinação à racionalidade externa da globalização financeira. Dessa forma, em um país que integra a América Latina, marcado por um movimento migratório diverso, não poderia deixar de buscar aproximações linguísticas com as formações socioespaciais locais, e nem tampouco adotar uma ação limitadora de sua cultura.

Por fim, o que essa reforma torna, é cada vez mais consistente a subordinação da Educação ao Mercado Econômico e torna mais viável atingir o objetivo do atual governo que é colocar o Brasil nos trilhos do desenvolvimento neoliberal. Nesse sentido, tornar os jovens com uma formação ética, estética e científica empobrecida faz parte desse intento, sobretudo quando a proposta envolve estudos e práticas que, do ponto de vista operacional, constitui-se em mudança no sentido de disciplinas e de professores habilitados, como é o caso da Geografia e da História que não tem lugar nessa reforma. 


\section{SEM SABER PENSAR O ESPAÇO GEOGRÁFICO E SEM SABER NELE AGIR: A DEFICIÊNCIA CÍVICA EMINENTE DADA À FALTA DO LUGAR DA GEOGRAFIA NO NOVO ENSINO MÉDIO}

Qual o lugar da Geografia no conjunto das Reformas Temer e, em particular, nessa reforma do Ensino Médio?

Entendemos que os processos aos quais o mundo de certa forma passou e vem passando, desde a década de 1970, e em particular o Brasil, desde o início da década de 1990, são os responsáveis pelo fato de o Ensino de Geografia assumir as posições curriculares que lhes são impostas. Esses processos são de natureza econômica, política e pedagógica. Neste tópico buscaremos refletir acerca dos impactos decorrentes da falta do saber e do conhecimento geográfico na vida de uma sociedade e, em seguida, discorremos sobre a natureza dos processos elencados responsáveis por essa situação.

A situação atual pela qual se encontra o Ensino de Geografia no Brasil evidencia o caráter complexo que é compreender a atividade educativa nacional. Isso implica, por um lado, uma análise de conjuntura política e econômica, e por outro lado, uma inquirição acerca das ideias pedagógicas que formatam os parâmetros, diretrizes e reformas educacionais.

De acordo com o geógrafo norte-americano David Harvey (2014), a partir dos anos de 1970 o mundo industrial passa por um processo de profundas reestruturações produtivas. Isso implicou inserção de tecnologia aos processos produtivos, em que o trabalhador passou a sofrer sérias consequências, como o desemprego e a sazonalidade deste, já que o desemprego passou a ser estrutural, impondo ao trabalhador adaptar-se aos novos padrões impostos pela reestruturação da produção (HARVEY, 2014). Essa situação implicou na perda da qualificação e passou a vigorar a noção de competência (RAMOS, 2006), que segundo essa mesma autora, busca atender pelo menos três propósitos, quais sejam: 
a) reordenar conceitualmente a compreensão da relação trabalho-educação, desviando o foco dos empregos e das tarefas para o trabalhador em suas implicações subjetivas com o trabalho; b) institucionalizar novas formas de educar/formar os trabalhadores e de gerir o trabalho internamente às organizações e no mercado de trabalho em geral, sob novos códigos profissionais em que figuram as relações contratuais, de carreira e de salário; c) formular padrões de identificação da capacidade real do trabalhador para determinada ocupação, de tal modo que possa haver mobilidade entre as diversas estruturas de emprego em nível nacional e, também, em nível regional (como entre países da União Européia e do Mercosul) (RAMOS, 2006, p. 39).

Essa situação não passou a fazer-se presente apenas nas empresas, mas também no ensino profissionalizante e também na escola, nas universidades, pois aí a noção de competência encontrou terreno fértil para o seu desenvolvimento (RAMOS, 2006; SAVIANI, 2013), pois estes espaços como são aparelhos ideológicos do Estado (ALTHUSSER, 1974), são a eles impostos racionalidades que buscam formatar um exército industrial de reservaiv para se controlar e/ou baratear os salários, através de uma pedagogia includenteexcludente. Veja-se, por exemplo, o que afirmam os Parâmetros Curriculares Nacional de Geografia do Ensino Médio com relação à promoção das competências: "[...] o aluno deve construir competências que permitam a análise do real, revelando as causas e efeitos, a intensidade, a heterogeneidade e o contexto espacial dos fenômenos que configuram cada sociedade" (BRASIL, 1998, p. 30; grifos nossos). Minada por essa concepção, a Educação caracteriza-se por uma série de dinâmicas que nos faz questionar a função social de tal proposta pedagógica. E uma reflexão não muito esforçada basta para percebermos que é moldar a sociedade aos processos de reprodução do capital e das elites econômicas e políticas nacionais em detrimento das necessidades e interesses da classe trabalhadora. É buscar adaptar a escola e o ensino às dinâmicas de reprodução do capital sem valores aos alunos, cujas necessidades imediatistas da tecnologia e dos discursos da flexibilização e do poder de autoescolha dão os parâmetros para essa formação. 
De acordo com Perrenoud (1999, p. 7), a noção de competência diz respeito a “[...] uma capacidade de agir eficazmente em um determinado tipo de situação, apoiada em conhecimentos, mas sem limitar-se a eles". Entendemos por essa assertiva que competência se refere aos sistemas de ações imediatas que a reestruturação produtiva exige dos sujeitos nesse meio e período técnicocientífico-informacional. Para tanto, às escolas Ihes são impostas a criarem um simulacro do mundo do trabalho, através das reformas educacionais que o Estado em conformidade com o Mercado Econômico empreitam e que problemáticas se desdobram a partir de então, pois “[...] quando se colocam em primeiro plano as práticas que apelam à competência, percebe-se uma espécie de desvalorização dos saberes acadêmicos ou especializados, bem como vontade de manter os empregados em um status de simples executantes" (DOLZ, OLLAGNIER, 2004, p. 11). Dessa forma, a lógica das competências insere-se em um processo permanente de adaptação dos sujeitos, propondo-lhes apreensões de capacidades e impondo-Ihes condição de aprendizes cada vez menos do domínio dos saberes formais ou escolarizados, já que estes acreditam, os adeptos dessa concepção, que pouco contribuem estes saberes para a mobilidade social, no atual contexto.

É isso que está acontecendo com a "nova" reforma do Ensino Médio, de modo particular e, com a Educação brasileira, de uma maneira geral, desde a década de 1990. O caso das palavras do geógrafo Milton Santos, em artigo intitulado Os Deficientes Cívicos, publicado originalmente em 24 de janeiro de 1999, na Folha de São Paulo, ilustra esse episódio:

Hoje, sob o pretexto de que é preciso formar os estudantes para obter um lugar num mercado de trabalho afunilado, o saber prático tende a ocupar todo o espaço da escola, enquanto o saber filosófico é considerado como residual ou mesmo desnecessário, uma prática que, a médio prazo, ameaça a democracia, a república, a cidadania e a individualidade. Corremos o risco de ver o ensino reduzido a um simples processo de treinamento, a uma instrumentalização das pessoas, a um aprendizado que se exaure precocemente ao sabor das mudanças rápidas e brutais das formas técnicas e organizacionais do trabalho exigidas por uma implacável competitividade. Daí, a difusão acelerada de propostas que levam a uma profissionalização precoce, à fragmentação da 
formação e à educação oferecida segundo diferentes níveis de qualidade, situação em que a privatização do processo educativo pode constituir um modelo ideal para assegurar a anulação das conquistas sociais dos últimos séculos. A escola deixará de ser o lugar de formação de verdadeiros cidadãos e tornar-se-á um celeiro de deficientes cívicos (SANTOS, 2002, p. 151; grifos nossos).

Atendendo aos anseios do Estado neoliberal e, no caso brasileiro, ao Estado fruto de um processo golpista, midiático, jurídico e parlamentar, liquidador dos direitos sociais e da classe trabalhadora, a falta que o Ensino de Geografia resultará como consequências sociais é, "um celeiro de deficientes cívicos" (SANTOS, 2002, p. 151). Isso em função de uma série de razões.

A primeira delas diz respeito ao fato dessa reforma reforçar, no país, a negação da cidadania aos brasileiros e brasileiras, embora o discurso do Estado perverso seja o de promoção da cidadania, quando na verdade ampliam-se a confusão entre cidadania e consumidor. As palavras de Santos (2007, p. 155) ilustram bem essa situação e nos chama a atenção para a importância da clareza quanto à definição da cidadania para a promoção de uma sociedade crítica e participativa:

Quando se confundem cidadão e consumidor, a educação, a moradia, a saúde, o lazer aparecem como conquistas pessoais e não como direitos sociais. Até mesmo a política passa a ser uma função do consumo. Essa segunda natureza vai tomando lugar sempre maior em cada indivíduo, o lugar do cidadão vai ficando menor, e até mesmo a vontade de se tornar cidadão por inteiro se reduz.

Portanto, uma sociedade em que não se promovem os direitos sociais e que ao invés disso se elabora a construção de consumidores, a deficiência cívica como consequência final é inevitável.

A segunda razão refere-se à elaboração de uma sociedade sem saber pensar o espaço em que se vive e sem saber nele agir. A história e a epistemologia da Geografia já evidenciaram a importância de se saber pensar o espaço geográfico para nele se saber agir (LACOSTE, 1988). O alemão Friederich Ratzel e o francês Paul Vidal de La Blache enriqueceram essa premissa geográfica. Não estamos a falar aqui daquela concepção dos "Estados-maiores" e nem tampouco da concepção dos professores, das quais nos falava Lacoste 
(1988). De acordo com esse autor, o saber pensar o espaço e o saber nele agir na perspectiva dos Estados-maiores diz respeito à ideia de dominação por parte de algumas minorias sendo, dessa forma, um saber estratégico de dominação, de controle, um saber vinculado às questões políticas e militares. Na perspectiva dos professores, essa premissa geográfica, na época, e ainda nos dias atuais, diz respeito ao não desvelamento, ao cortinamento dos propósitos elaborados pelos Estados-maiores, ou seja, refere-se a não criticidade por parte dos professores e dos alunos, que visa dar ao Estado sempre o maior controle daquilo que Ihes é conferido. Dessa forma, a não presença do Ensino da Geografia nessa "Nova" Reforma do Ensino Médio presta-se a essas concepções de controle do saber pensar o espaço e do saber nele agir por parte do Estado, ocultando a complexidade socioespacial, política e econômica do atual período e contribuindo para a formação de deficientes cívicos, pois “[...] a geografia não é uma ciência de fatos isolados simples, passíveis de serem conhecidos por si e em si" (MONBEIG, 1957, p. 7), e nem tampouco passíveis de serem conhecidos e apreendidos diluídos nos demais conhecimentos, já que é uma maneira particular de compreender a sociedade e sua existência.

Uma terceira razão a se mencionar é com relação ao fato dessa reforma marcar as incertezas da própria Geografia e dos profissionais dessa área do saber. Não sendo sequer mencionado na estrutura curricular, o saber geográfico a ser ensinado passa a ser uma incógnita. De igual modo encontra-se, também, o futuro dos profissionais docentes desse saber e conhecimento, já que não terá sentido formar profissionais para atuar em nenhum lugar. Isso é preocupante! Assim, aparecer como elemento transversal e/ou diluído nos demais eixos estruturantes desse novo currículo, a partir da alegação de que as disciplinas estão fora de uso é de uma estupidez tão grande que chega até ser um ato criminoso, pois se tira dos jovens direitos constitucionais já há muito garantidos. O sentido agora é desenvolver uma racionalidade educacional em que as 
disciplinas não são mais interessantes, mas a promoção de competências a serem desenvolvidas a partir de uma Base Nacional Comum Curricular.

A quarta razão diz respeito à agressão direta à Constituição Federal de 1988 (como atesta o inciso II do Art. 208) e à Lei de Diretrizes e Bases da Educação Nacional (LDB/1996), que garantem a universalidade do Ensino Médio enquanto etapa final da educação básica. Aliás, desta última normativa este princípio já foi retirado desde 2013, através da Lei Nº 12.796, de 4 de abril de 2013. A "Nova" Reforma do Ensino Médio engendrada pelo bloco de poder instaurado no país extermina a garantia do Ensino Médio enquanto etapa educacional básica e universal para a grande maioria dos jovens do pais, além de atrofiar e/ou reduzir o conhecimento que lhes são de direito construírem nessa etapa educacional para saber melhor agir na sociedade em que vivem.

Uma quinta razão, que, aliás, já vem desde a Lei Nº. 9.394/1996, em seu Art. 35․ Inciso II, está no fato de que, enquanto etapa final da Educação Básica, o Ensino Médio ter que fazer com que os jovens se adaptem com flexibilidade à novas condições de trabalho. Isso significa que a preocupação com uma formação profissional não é mais interessante, sobretudo quando o Ensino Técnico e Profissionalizante passa ser um destaque com essa "Nova" reforma. Isso não promove a cidadania, mas sim adestra-se para o Mercado Econômico e serve para o Estado ter mais controle sobre a massa social.

Os reformuladores da Educação nacional são incapazes de entender o significado, não apenas da Geografia para a promoção da cidadania, mas da Educação Básica como um todo. Uma renovação educacional que retira a Geografia enquanto disciplina da função curricular que ela pode desempenhar não é inocente. Obedientes aos comandos do Banco Mundial e da Organização Mundial do Comércio os compromissos desses reformuladores não são com a Educação Básica e nem com o direito universal, já que consideram a Educação como um serviço que tem que se adaptar às demandas do Mercado. A ausência 
do conhecimento geográfico, sobretudo dialético, impede que se possam perceber desmontes dos direitos sociais legalizados.

As reformas que visam formatar a classe trabalhadora brasileira do campo e da cidade, como é o caso dessa reforma do Ensino Médio, da previdência, trabalhista e aquela do congelamento dos investimentos em Educação e saúde públicas, por vinte anos, só se realizam em formações socioespaciais como o Brasil, porque ainda é carente o saber pensar o espaço geográfico e o saber nele agir no sentido da promoção da cidadania e dos direitos sociais.

No campo educacional e, em particular com relação à negligência do conhecimento geográfico que pensa a sociedade e sua existência com suas formas contraditórias, a "Nova" Reforma do Ensino Médio busca dar um direcionamento que visa camuflar o fato de que à classe trabalhadora é dada uma condição de seguir carreiras de menor prestígio social e de valor econômico inferior. Por isso, essa reforma "legaliza o apartheid social na educação no Brasil" (FRIGOTTO, 2016). Assim sendo, frente a esse contexto de reformas a população precisa, “[...] saber pensar o espaço para saber nele se organizar, para saber ali combater" (LACOSTE, 1988, p. 189) a tirania opressora do Estado vigente.

O sistema de ações intencionais do Estado é diminuir e/ou retirar do currículo disciplinas como a Geografia, com o discurso de que há um excesso de disciplinas no currículo do Ensino Médio. Para isso, usam um conjunto de discursos de engodo visando enganar os jovens e escondendo as reais condições da escola pública. Quanto aos jovens, sobretudo os filhos da classe trabalhadora Ihes fazem ver uma Educação como fábula, no sentido de que Ihes dizem que agora podem fazer escolhas nos seus currículos e ter uma vida melhor, camuflando a intencionalidade como ela realmente é: uma perversidade, uma vez que covardemente reforçam uma educação dual, cuja parte privilegiada se destina aos filhos dos que comandam a sociedade e que são treinados a futuramente dirigirem a sociedade. Quanto à escola tem-se uma escola degrada em todas as suas espacialidades físicas que caracteriza a educação pública 
nacional, de uma maneira geral: professores sem salários dignos e agindo de forma esfacelada dentro do seu tempo de trabalho, atuando em mais de uma escola para satisfazerem suas necessidades básicas, escolas sem laboratórios, sem auditórios etc.

A "Nova" Reforma do Ensino Médio não maximiza os conhecimentos dos jovens, pois ela míngua o conhecimento que os jovens precisam; reforça a desconstrução de uma visão crítica do mundo e das instituições ao retirar o saber pensar o espaço geográfico e o saber nele agir com o foco na promoção da cidadania e reforça o caráter dual, imprimindo e reforçando as desigualdades espaciais e sociais. Dessa forma, tal reforma obstaculiza os filhos da classe trabalhadora à universidade, dada essa formação incompleta.

Frente a isso, torna-se preocupante o cenário em que se encontra o Ensino da Geografia, pois está em jogo comprometedor a sua contribuição social tão importante à sociedade brasileira. Essa reforma contribui para marginalizar a função social que essa ciência e disciplina têm, e isso é inaceitável, já que é de uma perversidade muito grande.

O professor de Geografia é um sujeito extremamente importante. Não se quer dizer que os outros profissionais da Educação não os sejam também, mas que do ponto de vista social o professor de Geografia é mais essencial do que o profissional com notório saber , sobretudo “[...] para o avanço social, para as discussões sociais" (MORAES, 2002, p. 13), que tanto ainda faz falta na sociedade brasileira. Sociedade esta que tanto carece da promoção da cidadania e a Geografia tem sua parcela de contribuição na luta por essa empreitada, através da construção de uma visão socio-histórica, dialética, crítica, radical e totalizante dos fenômenos e processos sociais. Dessa forma, “O geógrafo incide diretamente na formação social do cidadão. O professor de Geografia está participando com um conteúdo e com uma temática essencial na formação da cidadania. A visão de mundo do estudante-cidadão, a visão do país, a visão da realidade local em que ele vive, tudo isso será profundamente permeado pelo conteúdo da Geografia 
escolar" (MORAES, 2002, p. 13-14). Sem isso, tem-se "deficientes cívicos" (SANTOS, 2002).

Retirar dos jovens a condição de saberem pensar o espaço geográfico é retirar deles a condição de saberem atuar no mundo de modo eficiente. É retirar deles a premissa de princípios geográficos fundamentais, como a própria localização que possibilita situar-se no mundo, ou seja, ter a consciência de está no mundo em relação aos demais sistemas de objetos e aos demais sistemas de ações e demais sujeitos socioespaciais. Dessa forma,

A autolocalização do indivíduo no mundo é essencial na formação da sua consciência social. O indivíduo precisa se localizar no mundo em variadas escalas, para entendê-lo e se entender nele. Então, na verdade o conteúdo da Geografia ilumina uma séria de campos que dizem respeito à construção de valores morais e à própria sociabilidade do indivíduo. Por isso, o professor de Geografia atua num terreno extremamente delicado, de alta responsabilidade social. Realmente, é uma tarefa extremamente importante, extremamente delicada e de uma responsabilidade social imensa, à qual nós temos que estar a todo momento atentos (MORAES, 2002, p. 14).

O Ensino de Geografia tem uma contribuição imensa à sociedade. O seu profissional, isto é, o professor de Geografia contribui imensamente para o desenvolvimento do raciocínio crítico dos jovens, concomitantemente, fornecendo-Ihes um conjunto de possibilidades essenciais para eles compreenderem o mundo e o seu funcionamento. Isso porque o professor de Geografia, consciente de sua condição e responsabilidade social, não passa uma visão fechada da realidade e nem tão pouco sectária, isto é, estreita, da vida social, mas uma explicação dialética, processual, espaço-temporal e técnica das condições sociais. Em outras palavras, o Ensino da Geografia possibilita “[...] estimular a reflexão política do aluno, porém, sem engessar essa reflexão política em modelos ideológicos acabados e inquestionáveis" (MORAES, 2002, p. 14). Frente ao atual cenário em que mergulha o Ensino de Geografia isso se constitui em uma dificuldade imensa, dado o arranjo curricular formatado pela "Nova" Reforma do Ensino Médio. Dessa maneira, comprometimentos negativos relativos ao Ensino de Geografia são apregoados pela Lei No. 13.415/2017: 1) o 
desenvolvimento do raciocínio crítico, sem passar uma visão fechada de mundo e nem estimular uma reflexão política míope amparada em modelos inquestionáveis; e 2) a promoção da valorização do multiculturalismo como emoliente da natureza constitutiva das formações socioespaciais que respeita o direito às diferenças e que desvela e alerta para as desigualdades socioespaciais.

A contribuição que o Ensino da Geografia possibilita à explicação da formação socioespacial brasileira é uma interpretação importante, já que tem uma centralidade na explicação da realidade social como um todo. O Ensino de Geografia precisa ser revalorizado no rol das Ciências Humanas como um todo e nos processos de dinâmicas da política educacional do país, “[...] sem dúvida nenhuma, a consciência da centralidade explicativa desta ciência, com relação à totalidade social, é um fato que hoje está evidente, mesmo quando lemos em autores de outras áreas" (MORAES, 2002, p. 19).

Caio Prado Júnior é um desses autores que afirmou a importância que tem a Geografia para o conhecimento do Brasil. Em entrevista à Folha de São Paulo, em 21 de maio de 1978, ele destacou a importância do conhecimento geográfico para a compreensão e ajuda na solução de problemas do país, a importância do professor de Geografia e a necessidade de valorização, neste país, do conhecimento geográfico:

História e Geografia são duas coisas que, infelizmente, sempre foram desleixadas no Brasil, sobretudo a Geografia. Geografia é fundamental. Geografia não é dizer que tem um rio de tantos quilômetros de comprimento. Geografia é compreender as condições naturais, humanas da vida, as relações, a distribuição, a maneira de viver. [...]. A Geografia foi que me abriu a perspectiva, e foi com o Defontaine - o maior professor que eu conheci na minha vida. Olha que eu conheci muito professor na minha vida, mas nenhum, de longe... o Defontaine batia todo mundo. Não que ele tivesse assim uma erudição, ele não tinha. Mas é porque é um homem que vivia o assunto. Para todo mundo que assistia às aulas dele era um divertimento, era um prazer, primeiro pelo entusiasmo dele. Ele tinha um amor, [...]. Grande professor, né? Professor não é o sujeito que sabe muito. Tem muita gente que sabe muito, mas não tem jeito nenhum pra ensinar. Ensinar tem toda uma comunicação, não? Então, como é que você vai conhecer um País, se você não conhece os meios e as condições de vida? Tem que se saber essas duas coisas: tem que saber Geografia, que é o lugar; e tem que saber História, que é a evolução. Existe no Brasil um grupo grande de estudiosos de Geografia, e não há dúvida 
nenhuma de que, como grupo, é aquele que conhece melhor o Brasil. No entretanto, eles não são tomados em consideração. Ninguém sabe nem da existência deles. Então fazem aí estradas e o diabo, mas não consultam os geógrafos. É preciso criar a mentalidade do geógrafo, que não se tem aqui. Então você vê o desastre que é São Paulo, é a falta disso (PRADO JR, 1978, n.p.).

Dessa forma, como destaca o historiador Caio Prado Jr., é preciso valorizarse mais o Ensino de Geografia no país e não o retirar e/ou o diluir nos demais itinerários formativos. Se vivemos em uma realidade socioespacial dialética esse conhecimento não pode ser deixado de lado, sobretudo no Brasil, em cuja condição de periférico e moderno, pobre e rico tem como síntese as desigualdades.

Uma leitura consistente, completa do mundo não pode ser feita sem o auxílio da Geografia. Se preocupando com a relação sociedade-natureza, produção do espaço, uso do território, a Geografia diz respeito à capacidade de existência humana no mundo, a partir desse olhar próprio dela, que tem procedimentos metodológicos muito específicos, como por exemplo: a observação, a descrição, a comparação, a análise, a explicação, a representação cartográfica. Assim, sendo, não é possível possibilitar formação de jovens sem a instrumentalização geográfica. Sem o saber pensar o espaço e sem o saber nele agir. Especialmente os filhos da classe trabalhadora, pois sem isso as possibilidades de uma construção cidadã se tornam impossíveis, já que "[...] a unidade dialética entre a leitura do mundo e a leitura da palavra que possibilita, cada vez mais, o atuar e o pensar sobre a realidade, suscitando a sua transformação" (FREIRE, 2006, p. 106), - fato possibilitado em grande medida pelo Ensino da Geografia - passa a ser um direito negado com a Lei Nº. 13.415/2017.

A Geografia é uma sabedoria essencial para o exercício da emancipação humana. Essa lei não tem a intenção de formar um cidadão completo, já que ela não se vincula à ideia de autonomia humana. Em primeiro lugar ela não faz parte de uma solução para crise na Educação, pois não existe essa crise na Educação, mas sim um projeto de desmonte centrado no processo de reprodução do capital 
nesse período técnico-científico-informacional, cujo arranjo organizacional extrapola as fronteiras nacionais. Em segundo lugar, essa reforma visa formar sujeitos de consciência dissociada, dando continuidade ao projeto nacional que trabalha para a manutenção de deficientes cívicos no território nacional, a partir da deformação da formação educacional. Assim, o “Novo” Ensino Médio não visa possibilitar aos jovens pensar em educação como formação, mas deformar sua formação, pois “[...] pensar em educação como formação é pensar em uma educação política, que reflete sobre si mesma, sobre seus limites e seus determinantes sociais, denunciando a instrumentalização da razão e da formação" (SANTANA, 2014, p. 10). Com essa reforma, os estudantes perdem sua condição de sujeitos, perdem sua autonomia, encontrando-se manipulados por forças repressoras presentes nessa reforma que dificultam cada vez mais a construção de uma consciência capaz de autorreflexão sobre si, sobre o mundo, sobre o espaço, sobretudo no atual período em que a Pedagogia das competências visa a todo instante contribuir para esse velamento. Sujeitos incapazes de estabelecer nexos entre a cultura e as grandes questões humanas e sociais e a extinção da carreira do professor de Geografia no país.

Por todas essas razões percebemos a importância do Ensino da Geografia e do professor dessa disciplina. Conforme Moraes (2002, p. 22),

Não há sistema de ensino adequado que não seja calcado na figura do professor. Não há boa educação sem um bom educador. Qualquer iniciativa, nesse setor, deve partir dessas primícias. Não adianta inovações teóricas, não adianta investimentos em infra-estrutura, não adianta nada disso, se não tocarmos nesse ponto básico: o professor e sua formação.

O professor de Geografia e sua formação, frente à "Nova" Reforma do Ensino Médio, nos coloca uma indagação: para onde vai a formação do professor de Geografia? Isso nos leva a uma investigação mais ampla, da qual as ideias pedagógicas que fundamentam essa reforma e a Educação nacional como um todo, possibilita-nos tecer algumas considerações. 


\section{NOVAS TERMINOLOGIAS, VELHAS IDEIAS PEDAGÓGICAS: AS BASES \\ ECONÔMICO-PEDAGÓGICAS, DIDÁTICO-PEDAGÓGICAS, PSICOPEDAGÓGICAS E PEDAGÓGICO-ADMINISTRATIVAS QUE FUNDAMENTAM A “NOVA” REFORMA DO ENSINO MÉDIO}

Quais as ideias pedagógicas que fundamentam a Reforma do Ensino Médio imposta pela Lei $N^{\circ} 13.415 / 2017$ ? Quais as teorias pedagógicas por traz dessa reforma? Para responder a esta pergunta vejamos, inicialmente, o que destacou Oliveira (1999) acerca dos Parâmetros Curriculares Nacionais de Geografia (PCN), pois entendemos, assim como Saviani (2013), que as ideias pedagógicas formatadoras da atual reforma do Ensino Médio é uma continuidade das reformas educacionais do país iniciadas na década de 1990.

Em primeiro lugar, Oliveira (1999) alerta para o fato problemático que o PCN de Geografia carrega em relação às contradições filosóficas. A postura desse documento oficial apresenta "[...] uma concepção de geografia [...] capaz de quebrar a visão de totalidade que a concepção dialética trouxe para o interior do pensamento geográfico" (OLIVEIRA, 1999, p. 54; grifos do autor). Essa mesma concepção se faz presente na Lei Nº 13.415/2017. Ou seja, ela contribui para a quebra de uma visão de totalidade dos processos sociais que possibilitam aos sujeitos conhecerem e compreenderem o mundo em que vivem e os negam a possibilidade de pensarem sua superação. Contribui para uma formação de pessoas que apenas se enxerguem “[...] como indivíduos, não conseguindo, portanto, enxergarem-se como classe" (OLIVEIRA, 1999, p. 54). Assim sendo, os autores dos PCNs sonegam aos leitores professores de Geografia a concepção filosófica sobre a qual escreveram este documento, fato que contribui para a elaboração de uma visão de sociedade, expressa nesta concepção, como “[...] uma reunião de indivíduos, e não a união contraditória de classes sociais em luta" (OLIVEIRA, 1999, p. 54), tal qual a "Nova" Reforma do Ensino Médio também mascara esse fato. 
Em segundo lugar, afirma Oliveira (1999, p. 55), que os autores do PCN de Geografia “[...] não concordam com o movimento crítico que dominou a geografia mundial [...]" no final do século XX. Isso significa a adesão à ideologia capitalista individualista propagada pela pedagogia das competências. Essa postura ideológica é a mesma presente na "Nova" Reforma do Ensino Médio, que visa retirar da Educação a possibilidade da construção da conscientização no tocante à transformação das realidades perversas do capital desigual e combinado que (des)organiza as formações socioespaciais. Assim, muitas são as passagens onde os autores dos PCNs procuram registrar sua posição contrária a uma concepção dialética na Geografia. Mas, assim como a Lei 13.415/2017 evidenciam uma posição ideológica que visa construir uma Geografia e uma Educação voltadas para os padrões flexíveis do mercado e direcionadas para valores individuais e individualistas (OLIVEIRA, 1999), o que contraria uma posição de classe, que por sua vez dificulta a luta por uma sociedade menos desigual e contribui para a dominação e alienação e intensifica a dualidade educacional no país.

Em terceiro lugar, Oliveira (1999) chama a atenção para o descuidado para com as questões teóricas presente no PCN de Geografia, apontando várias contradições com relação aos conceitos: espaço, território, paisagem, região e lugari. Isso representa uma característica, sobretudo, presente na atual reforma do Ensino Médio: a confusão e/ou, para parafrasear Bauman (2001), a liquidez, inconsistência, a ausência de referenciais com que são tratadas as questões nesse período técnico-científico-informacional, cujo objetivo é confundir mesmo. Dessa forma, segundo Oliveira (1999, p. 62), “[...] as bases conceituais da geografia presente nos PCNs carecem de rigor conceitual e consistência lógica. Este fato transforma o documento num verdadeiro 'samba do crioulo doido', sem fundamento e ornamentado por discurso retórico".

Em quarto lugar, "A concepção pedagógica implícita, presente no PCN de Geografia, revela [...] uma visão centrada no ensinamento de conteúdos pretensamente atuais e modernos, desprovidos de uma concepção formadora 
que permita a construção da autonomia do aluno" (OLIVEIRA, 1999, p. 63). Isso implica evidência da ausência da concepção pedagógica adotada, mas não a ideia pedagógica estruturante, que mesmo implícita, mas mediante as características do documento PCN como um todo revelam o neoprodutivismo e suas variantes, tais como o neoescolanovismo, o neoconstrutivismo e o neotecnicismo (SAVIANI, 2013) enquanto ideias pedagógicas estruturantes dessas concepções reformistas da Educação nacional. Nesse sentido, a Lei No 13.415/2017 deixa bem claro o caráter pedagógico assumido por essa reforma, pois segue o perfil educacional da década de 1990. Em primeiro lugar porque é comandada pela secretária executiva do Ministério da Educação que é da turma dos reformistas da Educação nacional da década de 1990 - Maria Helena Guimarães de Castro, - que já enfatizou a principal característica da ideia pedagógica presente nas reformas educacionais datadas desse período: “[...] só será cidadão pleno - participando ativamente do mundo social, do trabalho e da política - aquele que desenvolver as competências básicas exigidas para sua inserção na sociedade do conhecimento, que incluem: capacidade para resolver problemas; autonomia para buscar informações; capacidade de fazer escolhas e tomar decisões. Formar cidadãos com este perfil será o principal desafio da educação no próximo século" (CASTRO, 1999, p. 6; grifos nossos). Em segundo lugar porque o projeto dos reformuladores da Educação nacional é perverso e reforça a dualidade da Educação, já que é obediente à racionalidade do modo de produção em detrimento ao caráter democrático e humanizador de promoção da cidadania plena, ao qual se presta a Educação, tendo por traz as instituições financeiras internacionais, cujo foco é a introdução das políticas e doutrinas econômicas neoliberais na racionalidade educacional para garantir, cada vez mais, a reprodução do capital rentista, especulativo e financeiro, típico do regime de acumulação flexível. Em função disso, a Educação é considerada como um serviço e não como um direito e a escola passa a ser organizada e estruturada a partir de 
princípios organizacionais semelhantes aos da empresa, características do legado educacional do longo século XX brasileiro (SAVIANI et al., 2004; SAVIANI, 2013).

A marca principal do atual período histórico, dada pela conjugação da técnica, da ciência, da informação, da financeirização, da política, não é mais dinamização centrada nas máquinas mecânicas, mas coincide com a revolução da informática. No primeiro caso se tinha uma busca pela materialidade, na produção de novas materialidades (novos objetos); no segundo caso há uma centralização no mundo da comunicação, nas máquinas eletrônicas, na produção simbólica, ao passo que antes da produção dos objetos que vão configurar novas ações se produzem os símbolos, se simula em modelos computacionais (SANTOS, 2009; LYOTARD, 2009; HARVEY, 2014; SAVIANI, 2013). De igual modo, a racionalidade político-econômica nominada de neoliberalismo (HARVEY, 2008) visa, por um lado, atacar o Estado e regular por outro. Busca defender severamente o retorno ao Estado liberal com o discurso de cortar gastos do governo, privatizar serviços públicos, promovendo aversão às democracias de massa, equilíbrio fiscal, abertura cada vez mais intensa das economias nacionais ao mercado externo, reformas trabalhistas, previdenciárias, educacionais, etc. São racionalidades, de início, impostas pelos organismos internacionais e, agora, mais do que nunca, efetivadas e impostas a todo vapor pelas elites econômicas e políticas nacionais no Brasil. De acordo com Saviani (2013, p. 428), "Nesse novo contexto, as ideias pedagógicas sofreram grande inflexão: passa-se a assumir no próprio discurso o fracasso da escola pública, justificando sua decadência como algo inerente à incapacidade do Estado de gerir o bem comum". Dessa forma, buscando caracterizar essas ideias pedagógicas o referido autor afirma que a denominação das mesmas busca se firmar “[...] lançando mão das categorias precedentes às quais se antepõem prefixos do tipo 'pós' ou 'neo'. [...] neoprodutivismo, neoescolanovismo, neoconstrutivismo, neotecnicismo" (SAVIANI, 2013, p. 428). 
É essa a racionalidade pedagógica estruturante da "Nova" Reforma do Ensino Médio, bem como das reformas educacionais impostas à Educação nacional, a partir dos anos de 1990. Vejamo-las conforme Saviani (2013).

Para Saviani (2013), em termos de ideias pedagógicas que estruturam as reformas educacionais da década de 1991 a 2001 e, entendemos ser as mesmas que estão presentes reconfigurando as dinâmicas e os processos educacionais, atualmente, no Brasil, são: 1) o neoprodutivismo e a pedagogia da exclusão, cuja característica principal é dada pelas bases econômico-pedagógica de proveniência de reconversão produtiva; 2) o neoescolanovismo e a pedagogia do aprender a aprender, cuja característica é proveniente das bases didáticopedagógicas; 3) o neoconstrutivismo e a pedagogia das competências que visa reorientar as atividades construtivas das crianças através das bases psicopedagógicas; 4) o neotecnicismo e a pedagogia corporativa da qualidade total, cujo foco é reorganizar as escolas e redefinir o papel do Estado através das bases pedagógico-administrativas.

A primeira é fruto das crises da sociedade capitalista que eclodiu na década de 1970 que reestruturou os processos produtivos através da mudança na base técnica da produção, substituindo o modelo fordista de produção e organização da produção pelo modelo de produção e organização da produção toyotista. De acordo com Harvey (2014), o modelo fordista era apoiado na instalação de grandes fábricas que operavam com tecnologia pesada de base fixa e incorporavam os métodos tayloristas de racionalização do trabalho, visando a produção em série de objetos estandardizados, isto é, padronizados em larga escala e acumulados em grandes estoques. Já o modelo toyotista apoia-se em tecnologia leve, isto é, de base microeletrônica flexível e visa a produção de objetos diversificados em pequena escala, cuja pretensão é atender à demanda de nichos específicos do mercado e incorpora métodos just in time que dispensam a formação de estoques. Dessa forma, se no fordismo requeriam-se trabalhadores com estabilidade no emprego, no toyotismo requer-se 
profissionais que “[...] disputem diariamente cada posição conquistada, vestindo a camisa da empresa e elevando constantemente sua produtividade" (SAVIANI, 2013, p. 429).

Dada essa mudança, a educação escolar, através das reformas educacionais, é chamada a assumir novos papeis na formação desses trabalhadores, já que os mesmos precisam ser polivalentes em função da exigência da flexibilidade que se impõe e saberem de conceitos gerais, abstratos, sobretudo de ordem matemática (SAVIANI, 2013). Dessa forma, o significado que à escola foi imposto, a partir da década de 1990, no Brasil, “[...] deriva de uma lógica voltada para a satisfação de interesses privados, 'guiada pela ênfase nas capacidades e competências que cada pessoa deve adquirir no mercado educacional para atingir uma melhor posição no mercado de trabalho' (GENTILI, 2002, p. 51)" (SAVIANI, 2013, p. 430; RAMOS, 2006). Isso significa que não cabe mais o Estado ter a iniciativa de assegurar emprego através da preparação assegurada pelas escolas, mas que deverá ser

[...] o indivíduo que terá de exercer sua capacidade de escolha visando a adquirir os meios que lhe permitam ser competitivos no mercado de trabalho. E o que ele pode esperar das oportunidades escolares já não é o acesso ao emprego, mas apenas a conquista do status de empregabilidade. A educação passa a ser entendida como um investimento em capital humano individual que habilita as pessoas para a competição pelos empregos disponíveis. 0 acesso a diferentes graus de escolaridade amplia as condições de empregabilidade do indivíduo, o que, entretanto, não the garante emprego, pelo simples fato de que, na forma atual do desenvolvimento capitalista, não há emprego para todos: a economia pode crescer convivendo com altas taxas de desemprego e com grandes contingentes populacionais excluídos do processo. É o crescimento excludente, em lugar do desenvolvimento inclusivo que se buscava atingir no período keynesiano (SAVIANI, 2013, p. 430).

O "Novo" Ensino Médio vem nessa direção. Assenta-se na exclusão com o discurso da inclusão, de que agora o indivíduo pode fazer escolhas e que só ele é o responsável pelo seu sucesso e/ou fracasso. É uma situação que busca

[...] preparar os indivíduos para, mediante sucessivos cursos dos mais diferentes tipos, se tornarem cada vez mais empregáveis visando a escapar da condição de excluídos. E, caso não o consigam, a pedagogia da exclusão Ihes terá ensinado a introjetar a responsabilidade por essa condição. [...]. Portanto, 
se diante de toda essa gama de possibilidades ele não atinge a desejada inclusão, isso se deve apenas a ele próprio, a suas limitações incontornáveis. Eis o que ensina a pedagogia da exclusão (SAVIANI, 2013, p. 431).

A segunda, focada no lema aprender a aprender, tem como eixo do processo educativo os aspectos psicológicos, ênfase nos métodos em detrimento dos conteúdos, no aluno em detrimento do professor, no interesse em detrimento do esforço, na espontaneidade em detrimento da disciplina (SAVIANI, 2013). Com o neoescolanovismo

[...] o mais importante não é ensinar e nem mesmo aprender algo, isto é, assimilar determinados conhecimentos. O importante é aprender a aprender, isto é, aprender a estudar, a buscar conhecimentos, a lidar com situações novas. E o papel do professor deixa de ser daquele que ensina para ser o de auxiliar o aluno em seu próprio processo de aprendizagem (SAVIANI, 2013, p. 431).

A atual Reforma do Ensino Médio, calcada no aprender a aprender, impõe aos jovens a necessidade constante de buscarem se atualizar, para ampliarem a condição de empregabilidade que a eles é imposta. Essa ideia propagou-se na Educação nacional a partir da década de 1990 e se reafirma cada vez mais através das normativas do MEC, como é o caso dos PCNs, a referência à montagem dos currículos de todas as escolas do país. Isso significa que se trata, agora, de capacitar os jovens para adquirir novas competências e novos saberes, no sentido de que as novas relações entre conhecimento e trabalho passaram a exigir capacidades de iniciativa e inovação. Dessa forma, estruturada no neoescolanovismo as ideias pedagógicas que vem orientando as reformas educativas, a exemplo da imposta pela Lei № 13.415/2017, orienta também as práticas educativas em vários espaços. Tais práticas, como enfatiza Saviani (2013, p. 434),

[...] se manifestam com características light, espraiando-se por diferentes espaços, desde as escolas propriamente ditas, passando por ambientes empresariais, organizações não governamentais, entidades religiosas e sindicais, acadêmicas e clubes esportivos, sem maiores exigências de precisão conceitual e rigor teórico, bem a gosto do clima pós-moderno, 
O que passa uma falsa imagem aos sujeitos de que são eles que agora podem escolher o que estudar, como percebemos nas várias propagandas do MEC acerca do "Novo" Ensino Médio.

A terceira, focada na pedagogia das competências, dá as bases psicopedagógicas que reorientam as atividades educativas. As ideias pedagógicas de base neoconstrutivista direcionam a construção do conhecimento não para a percepção, mas para a ação de promoção de competências. A racionalidade educativa com o neoconstrutivismo tende a focar-se no êxito e não na verdade, focando-se no fim prático e não na construção explicativa, por exemplo. Não interessam concepções que esclareçam "[...] 'os esquemas representativos ou os conceitos verdadeiros que implicam inclusão de classes e relações'" (SAVIANI, 2013, p. 436), já que ao discurso e à prática neoconstrutivista cabe valorizar os saberes docentes centrados na experiência cotidiana, uma vez que se disseminou outra teoria de sustentação das ações docentes, ou seja, a teoria do professor reflexivo que tem como premissa a valorização desses saberes docentes mencionados. O foco do neoconstrutivismo, a exemplo do que percebemos no "Novo" Ensino Médio é a promoção de mecanismos que visam adaptar o comportamento dos jovens ao meio socioespacial do presente dinamizado pelos processos de reprodução e reestruturação do capital de base técnica-científicainformacional, financeira, midiática e político-jurídica. Assim, “Para a adaptação ao meio natural e material entrariam em cena as competências cognitivas; e os mecanismos de adaptação ao meio social seriam constituídos pelas competências afetivo-emocionais" (SAVIANI, 2013, p. 437). Por essas razões é que concordamos mais uma vez com Saviani (2013, p. 437), para quem

[...] a 'pedagogia das competências' apresenta-se como outra face da 'pedagogia do aprender a aprender', cujo objetivo é dotar os indivíduos de comportamentos flexíveis que lhes permitam ajustar-se às condições de uma sociedade em que as próprias necessidades de sobrevivência não estão garantidas. Sua satisfação deixou de ser um compromisso coletivo, ficando sob a responsabilidade dos próprios sujeitos que, segundo a raiz etimológica dessa palavra, se encontram subjugados á ‘mão invisível do mercado'. 
A quarta, isto é, o neotecnicismo, apresenta suas características através da reorganização da escola e da redefinição do papel do Estado, cujos princípios da qualidade total ${ }^{\text {vii }}$ e da pedagogia corporativaviii evidenciam as bases pedagógicoadministrativas das reformas educacionais impostas no Brasil desde a década de 1990. Também está ligada à introdução da pedagogia das competências nas escolas para adequá-las à racionalidade das empresas, buscando ajustar, tanto os trabalhadores, como os cidadãos "[...] ao tipo de sociedade decorrente da reorganização do processo produtivo" (SAVIANI, 2013, p. 438). Em função disso, percebemos que implicitamente nas reformas educacionais implantadas no país e, em particular na que impôs o "Novo" Ensino Médio, as escolas são chamadas a uma nova função, qual seja: abandonar o ensino centrado nas disciplinas de conhecimento, como é o caso de Geografia e História. Assim, caminham para um ensino centrado em competências referidas às situações determinadas, fato já evidenciado por Ramos (2006) e Saviani (2013) para o caso das reformas educacionais brasileiras a partir de 1990 e, que como percebemos, presente também até esse momento.

Segundo Saviani (2013, p. 438), “[...] a base da pedagogia tecnicista são os princípios de racionalidade, eficiência e produtividade, dos quais deriva o corolário relativo à obtenção do máximo resultado com o mínimo de dispêndios". Seguindo essa racionalidade, o intento das reformas educativas, a exemplo da imposta pela Lei № $13.415 / 2017$, é reduzir custos, encargos e investimentos públicos na área da Educação, muito embora o discurso dos reformuladores seja o contrário. Redefine-se, dessa forma, a função do Estado e da escola.

Essa orientação está em entrelinhas na própria lei e nas propagandas do MEC veiculadas na mídia televisiva, em que notamos que a avaliação se torna no principal papel a ser exercido pelo Estado, já que é o Estado que avalia o ensino em todos os níveis (BRASIL, 1996; BRASIL, 2017). Conforme Saviani (2013, p. 439), "Trata-se de avaliar os alunos, as escolas, os professores, e a partir dos resultados obtidos, condicionar a distribuição de verbas e a alocação dos 
recursos conforme os critérios de eficiência e produtividade". O objetivo disso é cada vez mais tratar o professor como um prestador de serviço, os alunos como clientes e a Educação um “[...] produto que pode ser produzido com qualidade variável" (SAVIANI, 2013, p. 440).

Em suma, as ideias pedagógicas presentes na Lei Nº 13.415/2017 não expressam nada de novo como se quer com a atual reforma do Ensino Médio Novo Ensino Médio -, pois tratam-se de incorporação e redefinição de velhas teorias pedagógicas. O que se tem de novo é o prefixo (neo) readaptando cada vez mais a Educação aos padrões racionais do Mercado: neoprodutivismo, neoescolanovismo, neoconstrutivismo e neotecnicismo, redefinindo a função do Estado para com esse direito social e subordinando cada vez mais a sociedade ao controle do Mercado Econômico, gerando uma sociedade de deficientes cívicos amparada numa concepção pedagógica desigual e contraditória, porque centrase numa racionalidade marcada por uma "exclusão includente" e por uma “inclusão excludente" (KUENZER, 2005), a partir da massa de empregáveis que constitui, através desses mecanismos normativos de reestruturação do Ensino e da Aprendizagem. A exclusão includente, se manifesta no mercado de trabalho, referindo-se ao sistema de ações do Estado e do Mercado Econômico, que visa excluir do mercado formal de trabalho e dos direitos trabalhistas e previdenciários o trabalhador, que excluído terá que se valer de competências e se inserir em outras lógicas organizacionais se subsistências: "com carteira assinada, mas com diminuição de salário e de direitos; como empregado de empresa terceirizada; ou trabalhando para a mesma empresa, porém na informalidade. Eis aí a exclusão includente" (SAVIANI, 2013, p. 442). A inclusão excludente, ocorre mais visivelmente no campo da Educação, a partir da inclusão de estudantes “[...] no sistema escolar em cursos de diferentes níveis e modalidades sem os padrões de qualidade exigidos para ingresso no mercado de trabalho" (SAVIANI, 2013, p. 442). Isso porque, em nome da lógica empresarial imposta e assumida pela escola que desconsidera os processos e apenas foca 
nos resultados, visando as estatísticas educacionais, não considera em sua avaliação os meios em que se faz Educação no país. Dessa forma,

[...] para atingir essas metas quantitativas, a política educacional lança mão de mecanismos como a divisão do ensino em ciclos, a progressão continuada, as classes de aceleração que permitem às crianças e aos jovens permanecer um número maior de anos na escola, sem o correspondente efeito da aprendizagem efetiva. Com isso, embora incluídas no sistema escolar, essas crianças e esses jovens permanecem excluídos do mercado de trabalho e da participação ativa na vida da sociedade. Consuma-se, desse modo, a 'inclusão excludente' (SAVIANI, 2013, p. 442).

Daí a importância das pesquisas não cessarem-se sobre essa temática. Há todo um projeto em construção e implementação no Brasil, cujo foco discursivo é de voltar-se para o passo, para práticas e sistemas de ações ultrapassadas com linguagem de inovação, cujo resultado é o aumento do abismo entre as classes que compõem a sociedade nacional, em que a Educação é área central de ataques e controle estratégico em nome da racionalidade econômica.

\section{PARA NÃO CONCLUIR... QUAL O FUTURO DA GEOGRAFIA E DO SEU ENSINO?}

Percebemos ao longo deste ensaio que a compreensão dos conceitos e definições pelos quais se liga a Reforma do Ensino Médio e, de um modo geral, as normas relativas à Educação nacional, não se explicam fora do contexto das transformações no mundo trabalho. Nisso, é fundamental perceber as rupturas e continuidades com o passado, os novos processos de produção e suas consequências, pois disso decorrem as diretrizes educacionais impostas através de leis/normas, como se notou com o "Novo" Ensino Médio imposto pela Lei №. $13.415 / 2017$.

Isso evidencia que o papel da Geografia, numa perspectiva libertadora, frente ao contexto de mudanças estruturais ligadas à Educação, precisa ser discutido, pois se encontra ameaçado, uma vez que os reformuladores desta pasta política importantíssima nacional defendem, em todas as circunstâncias, os interesses da classe dominante e, para essa finalidade, o "Novo" Ensino Médio 
concorre. Há tempos, na história desse país, foi diferenciado o que deveria ser ensinado aos detentores do poder e o que poderia ser socializado enquanto conhecimento escolar aos filhos da classe trabalhadora. A Lei № 13.415/2017 é continuidade desse processo excludente.

Precisamos cada vez mais discutir a premissa de que, mudando o mundo do trabalho mudam também as formas de organização da vida e da (re)produção do conhecimento. Atentando-se à história como processo, perceberemos que em decorrência da luta pela existência os grupos sociais são obrigados a criarem novas formas de organização do trabalho, modificando costumes, hábitos, formas de pensar para adequar-se às novas condições de vida criadas. Tal situação está ocorrendo com o ensino de todas as disciplinas e, em particular, com o Ensino da Geografia e precisamos atentar-se para o fato de que não cabe à Geografia a adaptar-se à atual circunstância "[...] justificar a perversidade da globalização e convencer a todos de sua inevitabilidade histórica, social e econômica" (SOUZA NETO, 1999, p. 14), pois os custos sociais são enormes sem o saber pensar o espaço e sem o saber nele agir, já que é isso que, dentre outros aspectos, visa a Lei N 13.415/2017.

É preciso que a forma de ler e explicar o mundo tomando como referência o conceito de totalidade, não no sentido de gerar sínteses superficiais como visa o "Novo" Ensino Médio, mas sistemas lógicos, coerentes e dialéticos, não se perca. E para que isso não ocorra, é preciso que ao Ensino da Geografia seja dado o seu reconhecimento no projeto de um país mais justo e menos desigual.

\section{REFERÊNCIAS}

ALTHUSSER, L. Ideología y aparatos ideológicos de Estado. Bueno Aires: Nueva Visión, 1974.

BAUMAN, Z. Modernidade líquida. Rio de Janeiro: Jorge Zahar, 2001.

BRASIL. Lei № 9.394, de 20 de dezembro de 1996. Presidência da República. Casa Civil. Subchefia para Assuntos Jurídicos. Brasília, 2017. Disponível em: http://www.planalto.gov.br/ccivil 03/leis/L9394.htm. Acesso em 09 de set. de 2017. 
BRASIL. MINISTÉRIO DA EDUCAÇÃO E DO DESPORTO. Parâmetros curriculares nacionais. Ensino Médio - Geografia. Brasília/DF. 1998. Disponível em: http://portal.mec.gov.br/seb/arquivos/pdf/cienciah.pdf. Acesso em 27 de set. de 2017.

BRASIL. Lei No. 13.415, de 16 de fevereiro de 2017. Presidência da República. Casa Civil. Subchefia para Assuntos Jurídicos. Brasília, 2017. Disponível em: http://www.planalto.gov.br/ccivil 03/ ato2015-2018/2017/lei/L13415.htm. Acesso em 25 de ago. de 2017.

BRASIL. Lei No. 12.796, de 4 de abril de 2013. Presidência da República. Casa Civil. Subchefia para Assuntos Jurídicos. Brasília, 2017. Disponível em: http://www.planalto.gov.br/ccivil 03/ Ato2011-2014/2013/Lei/L12796.htm\#art1. Acesso em 29 de ago. de 2017.

BRASIL. Plano Nacional de Educação (PNE), 2014-2024. Lei No. 13.005, de 25 de junho de 2014, que aprova o Plano Nacional de Educação (PNE) e dá outras providências. Brasília: Câmara dos Deputados, Edições Câmara, 2014. (Série legislação; n. 125).

CASTRO, M. H. G. de. A Educação para o século XXI: o desafio da qualidade e da equidade. Brasília: Instituto Nacional de Estudos e Pesquisa Educacionais, 1999.

CHESNAIS, F. (Org.). A mundialização financeira: gênese, custos e riscos. [Tradução de Carmem Cristina Cacciacarro; Luís Leiria; Silvana Foá e Valéria Coêlho da Paz]. São Paulo: Xamã, 1998.

CHESNAIS, F. (Org.). A finança mundializada: raízes sociais e políticas, configuração, consequências. [Tradução de Rosa Maria Marques e Paulo Nakatani]. São Paulo: Boitempo, 2005.

COMENIUS, J. A. Didática magna. 3. ed. São Paulo: Martins Fontes, 2006.

DOLZ, J.; OLLAGNIER, E. (Orgs). O enigma da competência em educação. Porto Alegre: Artmed Editora, 2004.

FREIRE, P. Pedagogia da Esperança: um reencontro com a pedagogia do oprimido. 13. ed. Rio de Janeiro: Paz e Terra, 2006.

FRIGOTTO, G. Reforma do Ensino Médio do (des)governo de turno: decreta-se uma escola para os ricos e outra para os pobres. 22/09/2016. Disponível em: http://www.anped.org.br/news/reforma-de-ensino-medio-do-des-governo-de-turno-decretase-uma-escola-para-os-ricos-e-outra. Acesso em 06 de ago. de 2017.

FUNDAÇÃO SISTEMA ESTADUAL DE ANÁLISE DE DADOS (SEADE). Os jovens e o gargalo do Ensino Médio Brasileiro. $\mathbf{1}^{\text {a }}$ Análise SEADE, $n^{\circ}$. 5, agosto de 2013. Disponível em: http://www.observatoriodopne.org.br/uploads/reference/file/193/documento-referencia.pdf. Acesso em 24 de ago. de 2017.

GRAMSCl, A. Os intelectuais e a organização da cultura. 4. ed. Rio de Janeiro: Civilização Brasileira, 1982.

HARVEY,D.O Neoliberalismo: história e implicações. Tradução de Adail Sobral e Maria Stela Gonçalves. São Paulo: Edições Loyola, 2008.

HARVEY, D. Do fordismo à acumulação flexível. In:__. Condição pós-moderna: uma pesquisa sobre as origens da mudança cultural. 25. ed. São Paulo: Edições Loyola, 2014. p. 135-162. 
KUENZER, A.Z. Exclusão includente e inclusão excludente: a nova forma de dualidade estrutural que objetiva nas novas relações entre educação e trabalho. In SAVIANI, D.; SANFELICE,J.L.; LOMBARDI, J. C. (Orgs.). Capitalismo, Trabalho e Educação. 3. ed. Campinas/SP: Autores Associados, 2005. p. 77-96.

LACOSTE, Y. A geografia: isso serve, em primeiro lugar, para fazer a guerra. Tradução de Maria Cecília França. Campinas: Papirus, 1988.

LIBÂNEO, J.C. Didática. 33ª reimpr. São Paulo: Cortez, 2011. (Coleção magistério. Série formação do professor).

LYOTARD, J-F. A condição pós-moderna. Tradução de Ricardo Corrêa Barbosa; posfácio de Silviano Santiago. 12ª ed. Rio de Janeiro: José Olympio, 2009.

MONBEIG, P. Papel e Valor do Ensino da Geografia e de Sua Pesquisa. In Novos Estudos de Geografia Humana Brasileira. São Paulo: Difusão Européia do Livro, 1957. p. 5-25.

MORAES, A.C.R. A contribuição social do ensino de Geografia. In Anais do ciclo de debates e palestras sobre reformulação curricular e ensino de Geografia. Departamento de Ciências Humanas e Integração Social/CAp/NAPE/DEPEXT/SR-3/UERJ, 2002.

OLIVEIRA,A.U. de. Geografia e ensino: os parâmetros curriculares nacionais em discussão. In CARLOS, A. F. A., OLIVEIRA, A. U. de. (Orgs.). Reformas no mundo da educação: parâmetros curriculares e Geografia. São Paulo: Contexto, 1999. p. 43-67.

PERRENOUD, P. Construir competências desde a escola. Porto Alegre: Artes Médicas, 1999.

PRADO Jr., C. Que país é este?. Entrevista à Folha de São Paulo em 21 de maio de 1978. Banco de Dados Folha. Acervo on line. Disponível em: http://almanaque.folha.uol.com.br/entcaioprado.htm. Acesso em 07 de set. de 2017.

RAMOS, M.N. Pedagogia das competências: autonomia ou adaptação? 3. ed. São Paulo: Cortez, 2006.

RUMMERT, S. M.; ALGEBAILE, E.; VENTURA, J. Educação da classe trabalhadora brasileira: expressão do desenvolvimento desigual e combinado. Revista Brasileira de Educação. v. 18; n. 54; jul-set., 2013. p. 717-799.

SANTANA, I. D. Formação em Adorno e Horkheimer. 199f. 2014. (Dissertação de Mestrado em Educação). Faculdade de Educação. Universidade Federal de Goiás. Goiás, 2014.

SANTOS, M. A urbanização brasileira. 2. ed. São Paulo: Hucitec, 1994. (Estudos urbanos; 5).

SANTOS, M. O retorno do território. In SANTOS, M.; SOUZA, M. A. A. de; SILVEIRA, M. L. (Orgs.). Território: globalização e fragmentação. Associação Nacional de Pós-Graduação e Pesquisa em Planejamento Urbano e Regional. São Paulo: Hucitec, 1998a. p. 15-20.

SANTOS, M. O professor como intelectual na sociedade contemporânea. Conferência de Abertura do IX ENDIPE - Encontro Nacional de Didática e Prática de Ensino, Águas de Lindóia - SP, 04 a 08 de 1998b.

SANTOS, M. Os deficientes cívicos. In__. o país distorcido: o Brasil, a globalização e a cidadania. Organização, apresentação e notas de Wagner Costa Ribeiro. São Paulo: Publifolha, 2002. p. 149-152.

SANTOS, M. O espaço do cidadão. 7. ed. São Paulo: Edusp, 2007. 
SANTOS, M. Técnica, espaço, tempo: globalização e meio técnico-científico informacional. 5. ed. São Paulo: Edusp, 2008a. (Coleção Milton Santos; 11).

SANTOS, M. Por uma Geografia Nova: da crítica da geografia a uma geografia crítica. 6. ed. $1^{\text {a }}$ reimpr. São Paulo: Edusp, 2008b. (Coleção Milton Santos; 2).

SANTOS, M. Espaço e método. 5. ed. São Paulo: Edusp, 2008c. (Coleção Milton Santos; 12).

SANTOS, M. A Natureza do Espaço: Técnica e Tempo. Razão e Emoção. 4. ed. São Paulo, Ed. Edusp, 2009. (Coleção Milton Santos; 1).

SANTOS, M.; SILVEIRA, M. L. O Brasil: território e sociedade no início do século XXI. 4. ed. Rio de Janeiro: Record, 2002.

SAVIANI, D. [et al.]. O legado educacional do século XX no Brasil. Campinas/SP: Autores Associados, 2004. (Coleção Educação Contemporânea).

SAVIANI, D. Sobre a Natureza e Especificidade da Educação. In Pedagogia históricocrítica: primeiras aproximações. 10. ed. rev. Campinas/SP: Autores Associados: 2008. (Coleção Educação Contemporânea). p. 11-22.

SAVIANI. D. O neoprodutivismo e suas variantes: neoescolanovismo, neoconstrutivismo, neotecnicismo (1991-2001). In História das ideias pedagógicas no Brasil. 4. ed. Campinas/SP: Autores Associados, 2013. (Coleção memória da educação). p. 425-442.

SILVEIRA, M. L. Um país, uma região: fim de século e modernidades na Argentina. São Paulo: APESP/LABOPLAN-USP. 1999. 488p.

SOUZA NETO, M. F. de. A Ágora e o Agora. Revista Terra Livre. n. 14. 1999. p. 8-20. Disponível em: http://www.agb.org.br/publicacoes/index.php/terralivre/issue/view/17. Acesso em 10 de set. de 2017.

i Lei №. 13.005, de 25 de junho de 2014.

ii "institucionalizar programa nacional de renovação do ensino médio, a fim de incentivar práticas pedagógicas com abordagens interdisciplinares estruturadas pela relação entre teoria e prática, por meio de currículos escolares que organizem, de maneira flexível e diversificada, conteúdos obrigatórios e eletivos articulados em dimensões como ciência, trabalho, linguagens, tecnologia, cultura e esporte, garantindo-se a aquisição de equipamentos e laboratórios, a produção de material didático específico, a formação continuada de professores e a articulação com instituições acadêmicas, esportivas e culturais" (BRASIL, 2014, p. 53; grifos nossos).

iii Tais constatações de Saviani tiveram como embasamento teórico Karl Marx, pois foi este quem evidenciou primeiro que "o trabalho como criador de valôres-de-uso, como trabalho útil, é inseparável da existência do homem, - quaisquer que sejam as formas de sociedade, - é necessidade natural e eterna de efetivar o intercâmbio material entre o homem e a natureza e, portanto, de manter a vida humana" (MARX, 1996, p. 50). Acrescenta ainda em outra obra que "Uma aranha executa operações semelhantes às do tecelão, e uma abelha envergonha muitos arquitetos com a estrutura de sua colmeia. Porém, o que desde o início distingue o pior arquiteto da melhor abelha é o fato de que o primeiro tem a colmeia em sua mente antes de construí-la com a cera. No final do processo de trabalho, chega-se a um resultado que já estava presente na representação do trabalhador no início do processo, portanto, um 
resultado que já existia idealmente" (MARX, 2013, p. 327). Tudo isso significa que "o trabalho é um processo entre o homem e a Natureza, um processo em que o homem, por sua própria ação, media, regula e controla seu metabolismo com a Natureza. Ele mesmo se defronta com a matéria natural como uma força natural. Ele põe em movimento as forças naturais pertencentes a sua corporalidade, braços e pernas, cabeça e mão, a fim de apropriar-se da matéria natural numa forma útil para sua própria vida. Ao atuar, por meio desse movimento, sobre a Natureza externa a ele e ao modificá-la, ele modifica, ao mesmo tempo, sua própria natureza. Atuando assim sobre a natureza externa e modificando-a, ao mesmo tempo modifica sua própria natureza" (MARX, 1983, p. 149).

iv “À medida que se implementam inovações técnicas poupadoras de mão-de-obra, tais ou quais contingentes de operários são lançados no desemprego, em que se mantêm por certo tempo, até quando a própria acumulação do capital requeira maior quantidade de força de trabalho e dê origem a novos empregos. Assim, a própria dinâmica do capitalismo atua no sentido de criar uma superpopulação relativa flutuante ou exército industrial de reserva" (MARX, 1996, p. 41).

v Estamos a dizer, e neste caso com Moraes (2002, p. 17), que não basta “[...] apenas o domínio do conteúdo específico da disciplina [para ensinar], mas também uma formação pedagógica e humanista ampla. Certos temas da Filosofia e da Ciência Política, por exemplo, se impõem na sua formação [do professor de Geografia], somando-se aos temas didáticos e pedagógicos, já comentados, e ao conteúdo específico da disciplina. [...]. Além do conteúdo específico da disciplina, além do conteúdo específico da Pedagogia, há a necessidade dessa formação crítica e humanista, em cujo campo básico nós teremos de avançar [...], sobretudo frente ao atual cenário em que se encontra o Ensino de Geografia". Dessa forma, "Ter uma visão clara da disciplina é um pressuposto básico para um bom ensino de Geografia" (MORAES, 2002, p. 18), coisa que falta ao profissional com notório saber.

vi “Os conceitos enumerados são produtos históricos de correntes diferentes de pensamento e foram sendo propostos com base em uma identidade epistemológica. Assim foi que o positivismo clássico formulou o conceito de paisagem geográfica para dar conta das características gerais formadoras de grandes extensões da natureza terrestre. Este conceito está presente em grande parte dos livros didáticos de geografia, que teimosamente permanecem sendo publicados. Também é o caso do conceito de região que se tornou central na escola historicista na geografia. Já que negando as possibilidades de elaborar leis gerais, como fizeram os positivistas, trataram de encontrar as particularidades únicas que formavam diferentes partes do ecúmeno. Os conceitos de espaço, território e lugar ganharam dimensões conceituais importantes na geografia com a influência do pensamento dialético" (OLIVEIRA, 1999, p. 61).

vii “O conceito de 'qualidade total' está ligado à reconversão produtiva promovida pelo toyotismo ao introduzir, em lugar da produção em série e em grande escala visando a atender a necessidade do consumo de massa, a produção em pequena escala dirigida ao atendimento de determinados nichos de mercado altamente exigentes. [...] o conceito de 'qualidade total' expressa-se em dois vetores, um externo e outro interno. Pelo primeiro vetor essa expressão pode ser traduzida na frase 'satisfação total do cliente'. Pelo segundo vetor aplica-se uma característica inerente ao modelo toyotista que o diferencia do fordismo: 
capturar, para o capital, a subjetividade dos trabalhadores. Nessa dimensão, 'qualidade total' significa conduzir os trabalhadores a 'vestir a camisa da empresa'. A busca da qualidade implica, então, a exacerbação da competição entre os trabalhadores que se empenham pessoalmente no objetivo de atingir o grau máximo de eficiência e produtividade da empresa" (SAVIANI, 2013, p. 439-440).

viii “Consumando o processo de adoção do modelo empresarial na organização e no funcionamento das escolas, as próprias empresas vêm crescentemente se convertendo em agências educativas, configurando uma nova corrente pedagógica: a 'pedagogia corporativa', que se dissemina principalmente no ensino de nível superior, com o beneplácito da própria política educacional. [...] A mesma diversificação de modelos respalda a abertura indiscriminada de faculdades e cursos guiados fundamentalmente pelos assim chamados interesses de mercado, no espírito das 'universidades corporativas' que se vêm multiplicando nos Estados Unidos por iniciativa das grandes empresas. Nesse contexto o educador, como tal, é ofuscado, cedendo lugar ao treinador: a educação deixa de ser um trabalho de esclarecimento, de abertura das consciências, para tornar-se doutrinação, convencimento e treinamento para a eficácia dos agentes que atuam no mercado" (SAVIANI, 2013, p. 440-441). 